\title{
On Measuring Compassion in Social Preferences Do Gender, Price of Giving, or Inequality Matter?
}

\author{
Linda Kamas \\ Department of Economics \\ Santa Clara University \\ lkamas@scu.edu
}

\author{
Anne Preston \\ Department of Economics \\ Haverford College \\ apreston@haverford.edu
}

October 2006

\begin{abstract}
This paper incorporates compassion into social preferences and tracks individuals' choices over ten allocation decisions, categorizing participants' behavior more precisely than previous work. Approximately two-thirds of participants exhibit consistent preferences in all ten exercises and other-regarding individuals are almost evenly split between inequity aversion and social surplus maximization. Women are significantly more likely than men to be inequity averters and less likely to be social surplus maximizers. A large majority of participants choose one or more allocations consistent with compassion but which reduce own payoff, increase inequality, or reduce social surplus. Individuals respond to lower prices of giving by being less self-interested and to larger payoff gaps by being more compassionate.
\end{abstract}

JEL classification: C91, D63, D64, J16 


\section{On Measuring Compassion in Social Preferences Do Gender, Price of Giving, or Inequality Matter?}

\section{Introduction}

Recent research on social preferences has focused on equity and efficiency concerns, leading to an ongoing debate as to whether inequity aversion or efficiency maximization better characterizes other-regarding behavior. However, there has been relatively little effort to identify or measure the importance of compassion or caring for those who are worse-off. While some models have included the possibility of maximin preferences incorporating concern for the worst-off, there has been no careful analysis of how important such preferences might be. This is a serious omission because it is likely that compassion may lead individuals to make non-selfinterested economic decisions under some circumstances, and failure to account adequately for the compassion motivation may lead to erroneous conclusions about peoples' preferences.

In order to analyze other-regarding behavior more completely, this paper extends recent models of social preferences by including compassion as a motivation. We define compassion to be greater concern for those who are less well-off and carefully embed compassion into the well-established motivations of inequity aversion and social surplus maximization. In our schema, compassion is exhibited when people are willing to accept a lower return for themselves, greater inequality or disadvantageous inequality, and/or a smaller social surplus in order to increase the payoff to those who are worse-off. This definition allows desires for equity and social surplus maximization to be tempered by concern for those less well-off. 
Disagreements in the literature on whether inequity aversion or social surplus maximization better characterizes peoples' preferences may be due to heterogeneous preferences. We show that identifying preferences based on just one or a couple of allocation decisions may be misleading. Instead, we conduct a set of experiments tracking individuals' choices in a sequence of allocation decisions that, when analyzed together, can separate out other-regarding motivations and categorize participants' behavior more precisely than previous work. The set of responses to ten allocation decisions allows us to categorize individuals in terms of their preferences and to evaluate the extent to which their choices are consistent with one type of social preference. This is an improvement on the existing literature that has derived conclusions based on one or a few allocation decisions without tracking each person's choices under numerous alternative allocation opportunities. By evaluating an individual's choices under alternative costs of being other-regarding and with different degrees of inequality between participants, we obtain a more robust classification of preferences. These categorizations allow us to evaluate the extent to which compassion is an important motivation in addition to those of inequity aversion and social surplus maximization.

We also use our experiments to investigate whether motivations behind other-regarding behavior vary by gender, major, and other socio-economic characteristics. If, among heterogeneous individuals, group members share defining preferences, experiments that do not carefully distinguish participants by gender or major may falsely conclude that the majority of people are either inequity averters or social surplus maximizers when this result is sensitive to the composition of individuals who have participated in the experiments. Finally, we examine how individuals respond to different costs of other-regarding decisions and to larger disparities in payoffs among participants in order to evaluate whether people respond to price changes and 
payoff gaps in predictable ways. Evaluating individual responses to changing incentives is especially important in the current context because individuals may be more motivated by compassion when others are much worse-off in that they receive a payoff that is extremely low in absolute or relative terms.

Our experiments provide a substantial amount of evidence supporting the importance of compassion in social preferences, with nearly sixty percent of those who can be classified falling in a compassionate category. While there is a considerable amount of heterogeneity in preferences, about two-thirds of the participants make decisions that are consistent with one of the social preference categories in all ten allocation decisions. We find these individuals roughly evenly split between inequity averters and social surplus maximizers, however, men are more often categorized as social surplus maximizers while women are more often inequity averters. The results also suggest that people respond to a lower price of giving and larger payoff inequality by becoming more compassionate.

\section{Previous Literature}

\section{II.A. Social Preferences}

In the recent literature on social preferences, authors differ in the motivations that they emphasize. ${ }^{1}$ Fehr and Schmidt (1999) and Bolton and Ockenfels (2000) focus on aversion to inequity as the dominant reason why some individuals give up own payoff for the good of others. Assuming that some individuals have a distaste for inequality, Fehr and Schmidt present a utility function which is positively related to own payoff but negatively related to the magnitude of the difference between own payoff and others' payoffs. Bolton and Ockenfels' specification of inequity aversion is quite different. In their model, individuals care that they receive a fair share

\footnotetext{
${ }^{1}$ Engelmann and Strobel (2005B) summarize social preference models and the experimental evidence testing them.
} 
of total payoff but are not concerned about inequalities in the payoffs to others. As Engelman and Strobel (2004) point out, Bolton and Ockenfels' middle class inequity averters would be unwilling to tax the rich to help the poor while Fehr and Schmidt's inequity averters would support such redistribution. Although empirical work of both sets of authors support their own particular descriptions of inequity aversion, Engelman and Strobel (2004), analyzing a set of distribution experiments designed to test the importance of the two types of inequity aversion head-to-head, conclude that the Fehr and Schmidt version outperforms the Bolton and Ockenfels specification.

Charness and Rabin's social preferences model (2002) presents a more general utility function which incorporates a desire for efficiency (maximizing the total payoff or social surplus) and concern for the person with the lowest payoff (maximin) in addition to inequality aversion. $^{2}$ Their empirical work supports the hypothesis that these first two motivations are more important than reducing inequality in instigating other-regarding behavior. Engelman and Strobel (2004) reinforce these conclusions, asserting that self-interestedness, desire for efficiency, and maximin preferences explain data from their experiments well. They downplay the partial success of the Fehr and Schmidt inequity averse model by noting that the Fehr and Schmidt predictions coincide with those of maximin preferences. ${ }^{3}$ However, it may be that the composition of students participating in experiments has led to these conclusions. Fehr, Naf, and Schmidt (2005) point out that economists may prefer efficiency more and equity less than do non-economists. They present experimental evidence that supports this assertion. Furthermore,

\footnotetext{
${ }^{2}$ While maximin preferences are compassionate, in many allocation decisions such preferences cannot be separated from a social surplus maximization motivation (since giving to the least well-off may also increase the total payoff) or inequity aversion (since giving to the least well-off may reduce inequality.) Thus, compassion has not adequately been measured. We incorporate a broader notion of compassion below and design the allocation decisions to identify compassionate behavior.

${ }^{3}$ In related work, Fisman, Kariv, and Markovits (2005A, 2005B) conclude from their experiments that the goal of maximizing total payoffs dominates inequity aversion in participants' preferences while Cox and Sadiraj (2005) argue that neither inequity aversion nor quasi-maximin preferences are consistent with their dictator experiments.
} 
there is some evidence that women are more likely to be inequity averters and men social surplus maximizers (Andreoni and Vesterlund (2001), Dickinson and Tiefenthaler (2002)). ${ }^{4}$ Given evidence that preferences are heterogeneous and that members of some groups may hold similar preferences, careful attention must be paid to the characteristics of those participating in experiments when drawing conclusions about social preferences of the population at large.

An additional difficulty in determining which type of social preferences is dominant among people is that allocation choices in experiments often are consistent with more than one of the postulated motivators. The overlap of preferences motivating a given choice calls for an examination of within-person responses to multiple allocation exercises. In addition, individuals' responses may depend on the particular set of allocation choices provided; the size of payoff gaps among participants or the cost of increasing equity or total payoffs may influence decisions. Our study addresses these problems by categorizing individuals' preferences based on a set of ten allocation choices and examining their responses to different payoff gaps or costs. We also compare social preferences between groups, e.g. men and women, economics/business and other majors, and groups with other socioeconomic characteristics in common.

\section{II.B. Compassion}

Incorporating notions of equity and efficiency into utility functions is part of a wellestablished tradition in economics where policy debates and social welfare functions acknowledge the necessary trade-offs between these competing goals. These motivations have been incorporated into recent models of individual social preferences, as discussed below. Some attention has been paid to concern for those less well-off by incorporating maximin preferences (often termed "Rawlsian"), that is, a preference for maximizing the income of the

\footnotetext{
${ }^{4}$ Eckel and Grossman (2000) and Crosen and Gneezy (2004) survey the literature on gender and preferences.
} 
worst-off person (Charness and Rabin (2002). But these motivations are difficult to separate since increasing the payoff to the lowest recipient may also entail reducing inequality or increasing the sum total of payoffs. In recent papers, Cox and Sadiraj (2005) and Engelmann and Strobel (2005A,2005B) have presented social preference functions that attempt to incorporate concern for those less well-off by characterizing individual's social preferences as having declining marginal utility in payoffs to others.

In order to adequately measure compassion, experiments must be designed to isolate this motivation from the others, that is, provide the participants with the opportunity to give up selfinterest, inequity aversion, and/or social surplus maximization in order to help those worse-off. In this paper, we embed compassion in inequity aversion and social surplus maximizing behaviors, allowing both a desire for equity for oneself and/or others to be coupled with an effort to protect the welfare of those worse-off and a desire for social surplus maximization that is simultaneously tempered by concern for those less well-off. We also test the assumption of Fehr and Schmidt (1999) that the disutility of disadvantageous inequality exceeds that of advantageous inequality; compassion may be evidenced by the opposite in that some people may be willing to accept greater disadvantageous inequality in order to help those who are worse-off. ${ }^{5}$

\section{II.C. Gender}

Gender differences in altruism have long claimed the attention of psychologists but only recently have economists considered this possibility. The experimental literature has examined the issue of gender differences in a number of different games, however, anonymous dictator games most accurately identify other-regarding or altruistic actions because they eliminate risk,

\footnotetext{
${ }^{5}$ Fehr and Schmidt (1999) cite Loewenstein, Thompson, and Bazerman (1989) who find that people prefer advantageous to disadvantageous inequality. While this may be self-evident in the dispute negotiations between two people that they study, this situation may not easily lend itself to compassionate choices.
} 
incentives for strategic giving, and possibilities for reciprocity. The studies examining differences in men's and women's responses in dictator experiments have found conflicting results. While Eckel and Grossman (1998), Baum, Kamas, and Preston (2006), and Kamas, Preston, and Baum (2005) find women to be more generous, Bolton and Katok (1995), Cason and Mui (1997), Ben-Ner, Kong and Putterman (2002), Cox (2002), and Dufwenberg and Muren (2002) report no significant gender differences in offers made by dictators.

Some dictator studies conclude that the more generous sex depends on the context: Andreoni and Vesterlund (2001) find that women are more generous than men when the price of giving is high while men give more when the price is low. Cox and Deck (2002) conclude that the more generous sex depends on the size of the stakes, degree of anonymity and possibility of reciprocity.

The disparity in findings is likely due to differences in the contextual situations of the experiments: the type of game played, the framing of the experiment, the size of payoffs and the personal cost of decisions made, the degree of anonymity, how participants are recruited, etc. Acting non-self-interestedly requires some motivation, and therefore, the context of the experiment can significantly affect the outcome. For example, Eckel and Grossman (1996) find that participants in dictator games offer much larger amounts of money when the recipient is a charity rather than an anonymous student. Croson and Gneezy (2004) argue that since women are more sensitive to social conditions of an experiment, their decisions will exhibit greater variability among experiments depending on the context, thus explaining the conflicting results on gender differences found in the various studies.

The inconclusive results of the experimental literature on gender differences may be due partly to the failure to consider adequately the motivations behind altruistic behavior. The 
various contexts of the studies may have elicited different motivations that prevent a sufficient accounting of gender differences. The recent literature on social preferences has addressed this issue of motivation behind non-self-interested economic decisions and presents a good laboratory in which to investigate differences in preferences by gender.

\section{Incorporating Compassion into Social Preferences}

We extend the traditional categories of decision-making motivations by modifying wellknown utility functions which represent self-interest, inequity aversion, and social surplus maximization (efficiency). The first category, self-interest, corresponds to the usual assumption in which the person's utility is unaffected by payoffs to others implying that $\mathrm{U}_{\mathrm{i}}(\pi)=\pi_{\mathrm{i}}$, where $\pi_{\mathrm{i}}$ is payoff to self. Category 2 corresponds to the Fehr and Schmidt (1999) inequity aversion model, where utility is given by:

$\mathrm{U}_{\mathrm{i}}(\boldsymbol{\pi})=\pi_{\mathrm{i}}-\alpha_{\mathrm{i}} 1 /(\mathrm{n}-1) \sum_{\mathrm{j} \neq \mathrm{i}} \max \left\{\pi_{\mathrm{j}}-\pi_{\mathrm{i}}, 0\right\}-\beta_{\mathrm{i}} 1 /(\mathrm{n}-1) \sum_{\mathrm{j} \neq \mathrm{i}} \max \left\{\pi_{\mathrm{i}}-\pi_{\mathrm{j}}, 0\right\}$.

where $\pi$ is a vector of payoffs to individuals $i=1, \ldots, n$, and $\alpha_{i} \geq 0,1>\beta_{i} \geq 0$ for all $\alpha_{i}$ and $\beta_{i}$. It is reasonable to assume that $1>\beta_{\mathrm{i}}$ so that the individual values his or her own payoff more than reducing advantageous inequality. The Fehr and Schmidt assumption discussed earlier that disadvantageous inequality provides more disutility than advantageous inequality, or $\alpha_{i} \geq \beta_{i}$, is labeled here as competitive inequity aversion. However, we allow for the possibility that some people may be more concerned about the welfare of those who have less than they, rather than more. In this case, that we label compassionate inequity aversion, $\beta_{\mathrm{i}}>\alpha_{\mathrm{i}}$. The questions in our experiments are designed to test whether $\alpha$ or $\beta$ is greater for individuals. Under our classification, compassionate inequity averters may be willing to accept more total inequality or 
greater disadvantageous inequality in order to raise payoffs to those who are worse off, while competitive inequity averters would not do so.

Category 3 incorporates concern for social surplus maximization. Here the utility function for such individuals includes a positive weighting $\left(\lambda_{\mathrm{ij}}\right)$ of the total social surplus or total payout as well as one's own payoff:

$\mathrm{U}_{\mathrm{i}}(\boldsymbol{\pi})=\left(1-\lambda_{\mathrm{ii}}\right) \pi_{\mathrm{i}}+\sum_{\mathrm{j}} \lambda_{\mathrm{ij}} \pi_{\mathrm{j}} \quad$ where $\lambda_{\mathrm{ij}} \geq 0$

$\lambda_{\mathrm{ij}}$ measures how individual i values payoffs to individual $\mathrm{j}$. Under this welfare function, people value an increase in others' income even if they themselves do not benefit. In the case where $\lambda_{\mathrm{ij}}=\lambda_{\mathrm{ik}}$ for all $\mathrm{j}$ and $\mathrm{k}$, the individual values the social surplus, but does not care whether an increase in payoff goes to better-off or worse-off people. We term this efficiency maximizing. ${ }^{6}$ If $\lambda_{\mathrm{ij}}=1$ for all $\mathrm{i}, \mathrm{j}$, the individual seeks to maximize social surplus without special regard for self (giving to self and others are perfect substitutes). ${ }^{7}$ However, compassionate preferences may lead some individuals to prefer seeing those less well-off receive higher income, so that $\lambda_{\mathrm{ij}}>\lambda_{\mathrm{ik}}$ for $\pi_{\mathrm{j}}<\pi_{\mathrm{k}} \cdot{ }^{8}$ It may even be the case that for very low $\pi_{\mathrm{j}}$ 's, $\lambda_{\mathrm{ij}}$ may exceed one so that the individual is willing to give up his or her own income to transfer an equivalent amount to the other person. ${ }^{9}$ We categorize those who place a higher value on income of those who are worseoff in the income distribution as compassionate social surplus maximizers, because such

\footnotetext{
${ }^{6}$ Since these people care about their own return as well as efficiency, they might be called "egocentric efficiency maximizers" following Cox and Sandiraj's (2004) terminology. For ease of exposition, however, we call these people "efficiency maximizers" noting that self-interest may temper desires for surplus maximization. Similar considerations hold for compassionate social surplus maximizers.

${ }^{7}$ Andreoni and Vesterlund (2001) find some individuals choose allocations that maximize social surplus, treating giving to self and others as perfect substitutes.

${ }^{8}$ Cox and Sandiraj's (2004) egocentric altruism and Engelmann and Strobel's (2005A, 2005B) generalized quasimaximin preferences make a similar assumption.

${ }^{9}$ In this case we must also assume that the marginal utility to self of another's payoff is always greater than or equal to zero and that the increased contributions to own utility from an increase in payment to another person will be greater for those with lower initial payments than those with higher initial payments. These conditions are $\partial \mathrm{U}_{\mathrm{i}} / \partial \pi_{\mathrm{j}}>0 ; \partial^{2}\left(\mathrm{U}_{\mathrm{i}}\right) / \partial \partial \pi_{\mathrm{j}}<0$.
} 
individuals favor higher income for others, particularly those who are worse-off. Compassionate social surplus maximization is related to the maximin motivation whereby decisions are made to maximize the income going to the worst-off, however it differs because compassionate social surplus maximizers are also willing to increase incomes to those better-off and may accept a lower payoff to the worst-off if the surplus rises enough.

The salient details of the different utility functions can be illustrated with a graph where $\mathrm{U}_{\mathrm{i}}\left(\pi_{\mathrm{i}}, \pi_{\mathrm{j}}\right)$ is measured on the vertical axis and $\pi_{\mathrm{j}}$, payoff to person $\mathrm{j}$, is measured on the horizontal axis. Figure $1 \mathrm{~A}$ gives the utility function of a purely self-interested individual with payoff $\pi_{\mathrm{i}}$. It is a horizontal line since payoff to person $\mathrm{j}$ has no impact on person i's utility; person $\mathrm{i}$ is indifferent between allocation choices $\mathrm{A}, \mathrm{B}$, and $\mathrm{C}$ where person $\mathrm{j}$ receives a progressively higher payoff. With increases or decreases in own payoff, $\pi_{\mathrm{i}}$, the horizontal utility function will shift up or down. The self-interested person i will not accept a lower own payoff in order to increase the payoff of person $\mathrm{j}$ and he or she would accept a higher payoff at the expense of a lower payoff to $\mathrm{j}$.

Figure 1B gives the utility functions of inequity averters. Here, for the range of payoff to person $\mathrm{j}\left(\pi_{\mathrm{j}}\right)$, between 0 and $\pi_{\mathrm{i}}$ (own payoff), the utility of person i will increase, thus the initially positively sloped line. However, once $\pi_{\mathrm{j}}$ increases above own payoff, $\pi_{\mathrm{i}}$, utility falls as $\pi_{\mathrm{j}}$ rises. Therefore, utility peaks at $\pi_{\mathrm{j}}=\pi_{\mathrm{i}}$. The two types of inequity averters are represented, the compassionate inequity averter where $\beta>\alpha$ and the competitive inequity averter where $\alpha \geq \beta$. For illustrative purposes, utility is assumed to peak at the same level at $\pi_{\mathrm{j}}=\pi_{\mathrm{i}}$ for both types of inequity averters. Because the compassionate inequity averter cares more about those who are worse-off, when $\pi_{\mathrm{j}}$ falls, utility declines more than it declines when $\pi_{\mathrm{j}}$ rises. The opposite holds for competitive inequity averters. Figure 1B illustrates the difference in allocation choices for 
Figure 1A - Utility for Self-Interested

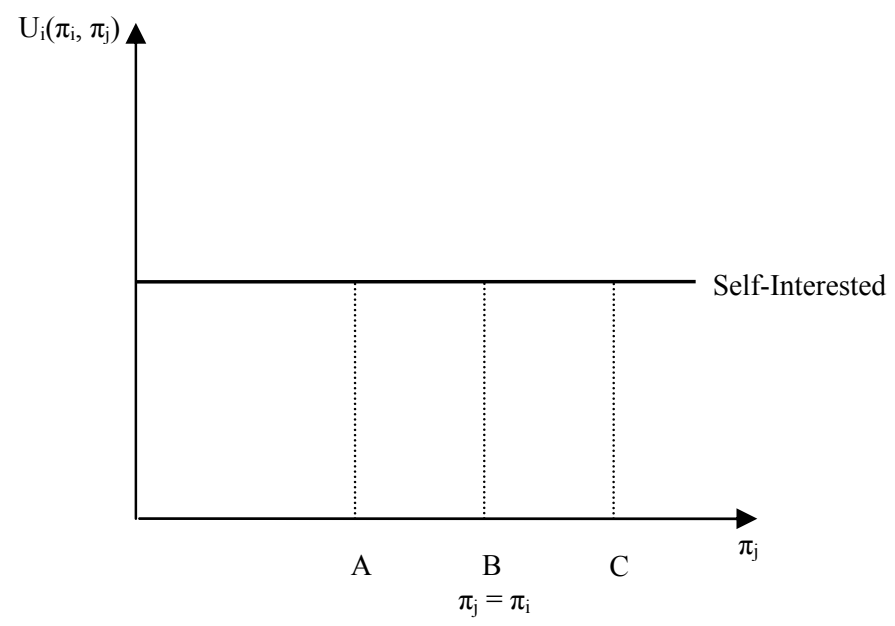

Figure 1B - Utility for Inequity Averters

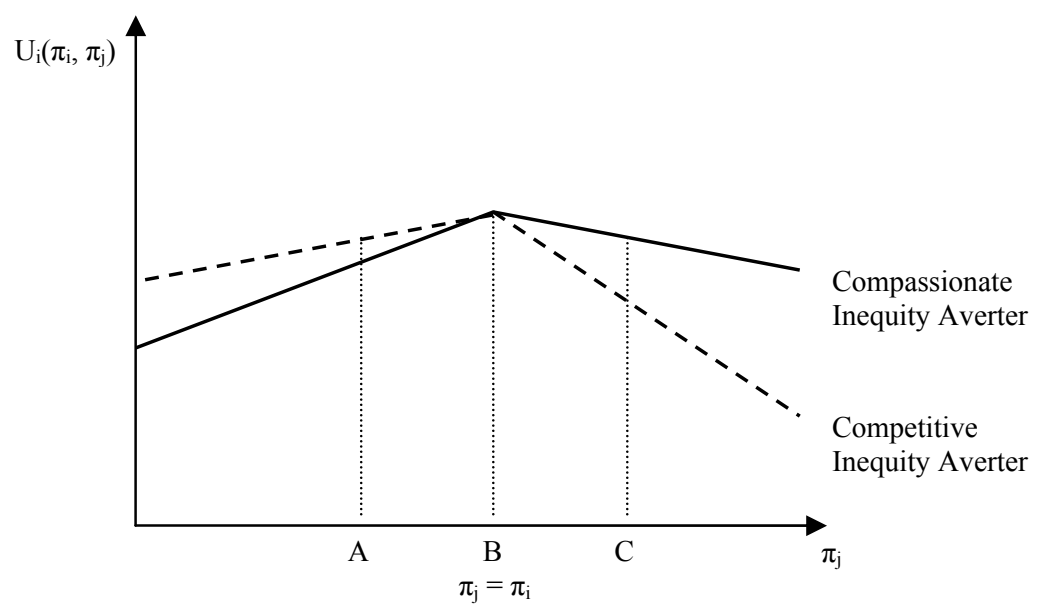

Figure 1C - Utility for Social Surplus Maximizers

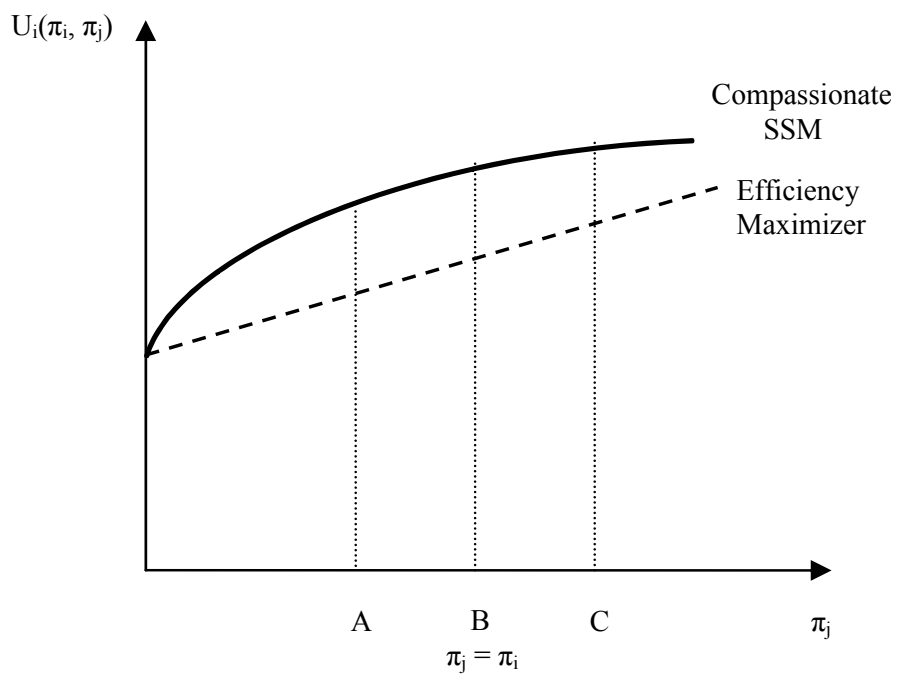


competitive and compassionate inequity averters. While both prefer equality (allocation B), faced with allocation choices A and C only, where person i has the same payoff but the payoff to the other is lower or greater by the same dollar amount, the competitive inequity averter would choose allocation $\mathrm{A}$ in order to avoid disadvantageous inequality while a compassionate inequality averter would choose allocation C, since it helps the other without hurting oneself and the amount of inequality is no greater than choice A.

Figure 1C provides the graphs of social surplus maximizers with the utility of the efficiency maximizer having an intercept of $\mathrm{U}_{\mathrm{i}}\left(\pi_{\mathrm{i}}, 0\right)$ and slope $\lambda_{\mathrm{ij}}$, which is a constant greater than zero but less than or equal to one. The utility function of a compassionate social surplus maximizer is also positively sloped through the range of $\pi \mathrm{j}$ 's, but the slope gets flatter for larger values of $\pi_{\mathrm{j}}$ because $\lambda_{\mathrm{ij}}$ declines. (For illustrative purposes, the intercept is assumed to be the same for efficiency and compassionate social surplus maximizers.) For a given payoff to self, both efficiency maximizers and compassionate social surplus maximizers will choose allocation. C in favor of A or B. Again the utility curve will shift up or down with higher or lower own payoff.

These graphs illustrate the difficulty in identifying preferences based on only one allocation decision. For example, if offered a choice between allocations A and $\mathrm{C}$ only, a choice of allocation $\mathrm{A}$ is consistent with self-interest and competitive inequity aversion while a choice of $\mathrm{C}$ is consistent with self-interest, compassionate inequity aversion, efficiency, and compassionate social surplus maximization. On the other hand, offering the choices of B and C only would separate inequity averters who would choose B from social surplus maximizers who would choose $\mathrm{C}$, but would not identify either the compassionate in the two categories or the self-interested. In the experiments we carry out, by carefully designing the allocation choices, 
we are able to categorize people by the set of answers they provide to ten allocation exercises. For example, someone who answers $\mathrm{C}$ in the first case above (A vs. C) and B in the second (B vs. C) has made choices consistent with compassionate inequity aversion but not consistent with competitive inequity aversion or either type of social surplus maximization. Since any choice where one does not have to give up anything is compatible with self-interest, in order to ascertain whether individuals are self-interested, we also offer allocation choices where equity or total payoffs are greater at the expense of a lower payoff to self.

In allocation decisions that entail some loss to self, the self-interested person will choose the allocation that provides him or her with the highest payoff. Inequity averters or social surplus maximizers may choose allocations at some loss to themselves if the increase in payoff to the other is high enough relative to the loss to self and/or if the weight to own payoffs is low relative to other's payoff. For inequity averters, individuals will accept a lower payoff in order to increase that of someone worse off if: $-\Delta \pi_{i}<(\beta / 1-\beta) \Delta \pi_{j}^{10}$. Social surplus maximizers will accept a lower payoff when person j receives more if: $-\Delta \pi_{\mathrm{i}}<\lambda_{\mathrm{ij}} \Delta \pi_{\mathrm{j}}+\Delta \lambda_{\mathrm{ij}} \pi_{\mathrm{j}}$.

Figure 2A shows this situation for inequity averters. The higher curve gives utility associated with own payoff $\pi_{\mathrm{i}}$, and the lower curve gives the utility associated with the lower own payoff of $\pi_{\mathrm{i}}$ - c. However an allocation of A, small payoff to other but higher own payoff on the higher utility function, generates less utility than B, equal payoffs to self and other but lower own payoff on the lower utility function. When faced with choice between A and B, this person would chose B, giving up some of own payoff in order to increase equality. Similarly in Figure

\footnotetext{
${ }^{10}$ Inequity averters will not choose an allocation that increases the payoff to the other person if he or she has a higher payoff than oneself.
} 
Figure 2

Allocation Choices with Payoff Loss to Self of \$c

Figure 2A

Allocations Entailing Loss to Self

for Inequity Averter with

Relatively High Weights on Other

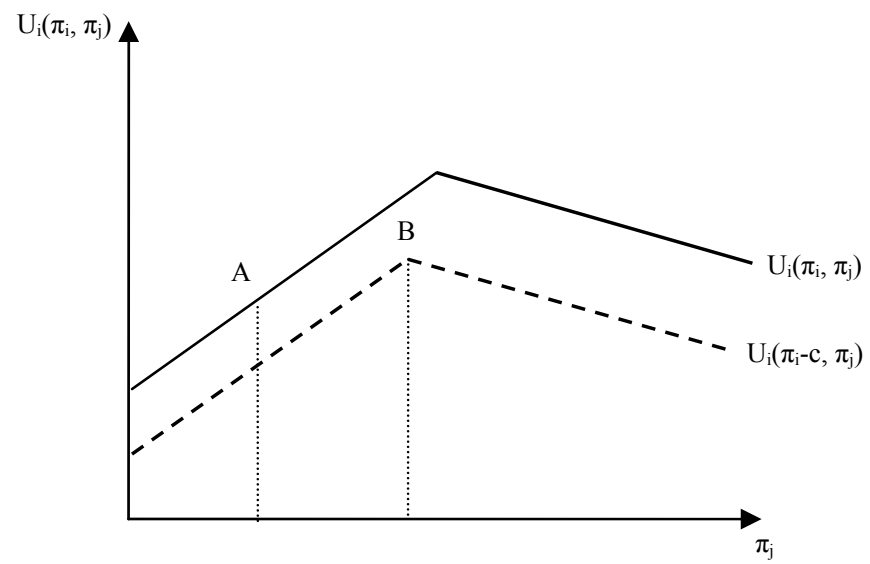

Figure 2C

Allocations Entailing Loss to Self for Social Surplus Maximizer with

Relatively High Weights on Other

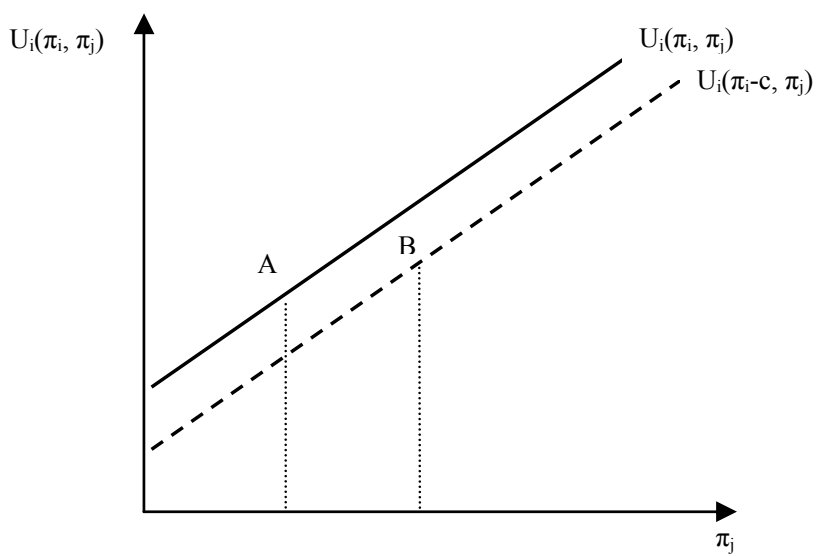

Figure 2B

Allocations Entailing Loss to Self for Inequity Averter with Relatively Low Weights on Other

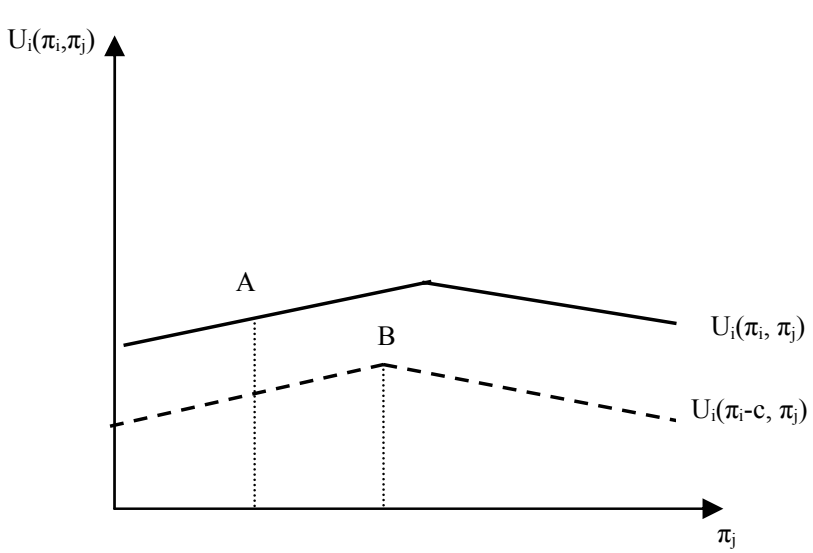

Figure 2D

Allocations Entailing Loss to Self for Social Surplus Maximizer with Relatively Low Weights on Other

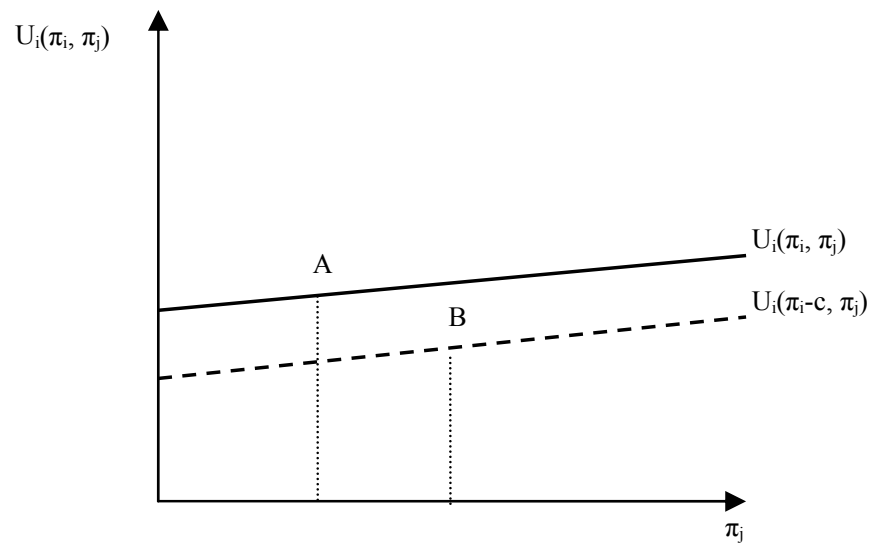


$2 \mathrm{C}$, the social surplus maximizer would choose $\mathrm{B}$ for a higher total payoff at the expense of a lower own payoff than A where own payoff is higher. Because compassionate inequity averters and compassionate social surplus maximizers place a higher weight on the welfare of those who are worse-off than on those better-off, they are more likely to be willing to accept a loss in their own payoff in order to increase the payoffs of those worse-off than are competitive inequity averters or efficiency maximizers. On the other hand, inequity averters and social surplus maximizers who place a high relative weight on own payoff may choose allocations which offer more to self at the expense of others even though they are not purely self-interested individuals (points A on Figures 2B and 2D). In addition, even for those individuals where the relative weight of own payoff is not large, allocations that require extremely large decreases in payoff to self may eventually lead the most other-oriented individuals to choose the allocation that provides the higher payoff for self. These graphs illustrate why different studies drawing conclusions from just one or a few decisions may obtain different results because they provide allocation choices where the costs of being non-self-interested and/or the payoff gaps differ.

Note that the utility functions of inequity averters and social surplus maximizers deviate markedly when the payoff to other starts to exceed payoff to self. Therefore, the social preferences associated with other-regarding behavior are quite different. It is unlikely that someone who has displayed a clear preference for inequity aversion would ever pick an allocation consistent with social surplus maximization yet inconsistent with inequity aversion (that is, chose an allocation that increases payoff gaps by increasing payoff to the other.) One cannot imagine that for very high levels of $\pi_{\mathrm{j}}$ utility of person i would turn up after having a negative slope. The alternative may not be as unlikely, at least for compassionate social surplus maximizers who may find that at high and increasing levels of $\pi_{\mathrm{j}}$ the utility of individual i may 
eventually start to decline as the slope gets smaller. The graphs reveal that, if individuals are rational, there should not be much, if any, switching between inequity averse behavior and social surplus maximizing behavior for allocations in the ranges of usual experiments.

\section{Experimental Design}

The experiments were run in classes and the psychology lab utilizing students from a wide variety of majors. The questions in the experiments were designed to identify economic decisions as falling in the five categories outlined above and summarized in Table 1. The participants were asked to choose the most preferred of three allocations of payments among himself or herself and two other anonymous students in the room, with the recipients labeled person X, Y (for "you"), and Z. Ten allocation decisions were made, and at the end of the experiment one was randomly chosen to be paid out. Each student was paid according to the allocation decision he or she made and also received payment as person $\mathrm{X}$ and $\mathrm{Z}$ from others' allocation choices. The anonymity of the participants was preserved by the use of code words and by having one person put the money in the envelope and a different person handing the envelope to the participant.

In the analysis, we first utilize all ten questions to categorize the participants according to the schema of Table 1. These questions incorporate a diverse set of circumstances in terms of the cost of choosing other-directed allocations and degree of inequality so they provide a strict test of the appropriate classification and consistency of peoples' preferences. Subsequently, in order to evaluate how individuals respond to payoff gaps and costs, we categorize preferences of individuals using only the first four questions. These four questions offer moderate tradeoffs in terms of the relative costs between choices and the payoff gaps or inequality among the recipients. As such, they serve as a benchmark to categorize the participants' social preferences. 
The rest of the questions in the experiment are then used to evaluate the stability of participants' preferences and their responses to alternative costs and payoff gaps.

Table 1 provides the allocation decisions and details the categorization of responses. The first five columns give the possible allocations for each question and the sum of the total amount paid out ("social surplus"), where the individual must decide between allocation A, allocation B, or allocation C. This was the information provided to the students in the questionnaire. The next two columns provide the difference in payouts between the person making the decision and persons X (column 6) and Y (column 7) in order to identify both the amount of inequality and the degree to which the inequality consists of higher or lower payouts relative to the decision maker. The rest of the columns identify the choices $(\mathrm{A}, \mathrm{B}$, or $\mathrm{C})$ that are consistent with each motivation. For example, consider question 1. The decision consistent with self-interest (no concern for the payoff to others) is $\mathrm{C}$, the allocation where the decision-maker has the highest payout. Choosing B over C would involve giving up two dollars while giving the two other players four dollars each. Both inequality averters and social surplus maximizers may find that B compares favorably to $\mathrm{C}$ since it both reduces inequality and increases the total payoff, but they may also choose $\mathrm{C}$ based on their own self-interest. When comparing $\mathrm{A}$ to $\mathrm{B}$, the decisionmaker receives the same amount but the payoffs to others have fallen, reducing the total social surplus while decreasing inequality. Inequality averters will find that A dominates B (although it is possible, but not likely, that compassionate inequity averters could choose B since it increases the income to the less well-off person, Z) and social surplus maximizers will find B dominates A since the social surplus is larger. For both these groups the comparison to the self-interested answer $\mathrm{C}$ depends on the extent of preferences for equity or efficiency relative to self-interest 
Table 1

Categorization of Allocation Choices

\begin{tabular}{|c|c|c|c|c|c|c|c|c|c|c|c|c|}
\hline I & II & III & IV & V & VI & VII & VIII & IX & $\mathbf{X}$ & XI & XII & XIII \\
\hline & \multirow{2}{*}{\multicolumn{3}{|c|}{ Distribution }} & \multirow{4}{*}{$\begin{array}{c}\text { Total } \\
\text { Payoff }\end{array}$} & \multirow{4}{*}{$\begin{array}{l}\text { Diff. } \\
\text { Self } \\
\text { to X }\end{array}$} & \multirow{4}{*}{$\begin{array}{l}\text { Diff. } \\
\text { Self } \\
\text { to Z }\end{array}$} & 1 & \multicolumn{2}{|c|}{2} & \multicolumn{2}{|r|}{3} & \\
\hline & & & & & & & $\begin{array}{c}\text { Self- } \\
\text { interested }\end{array}$ & \multicolumn{2}{|c|}{$\begin{array}{l}\text { Inequity Averse } \\
\text { (IA) }\end{array}$} & \multicolumn{2}{|c|}{$\begin{array}{c}\text { Social Surplus Max } \\
\text { (SSM) }\end{array}$} & \\
\hline & & & & & & & & $(2 \mathrm{~A})$ & (2B) & $(3 \mathrm{~A})$ & (3B) & \\
\hline & $\mathrm{X}$ & YOU & $\mathrm{Z}$ & & & & & $\begin{array}{l}\text { Competitive } \\
\text { IA }\end{array}$ & $\begin{array}{c}\text { Compassionate } \\
\text { IA }\end{array}$ & $\begin{array}{l}\text { Efficiency } \\
\text { Max }\end{array}$ & $\begin{array}{c}\text { Compassionate } \\
\text { SSM }\end{array}$ & CATEGORYa \\
\hline \multicolumn{13}{|l|}{1} \\
\hline A & 6 & 6 & 5 & 17 & 0 & 1 & $\mathrm{C}$ & $\mathrm{A}, \mathrm{C}$ & $\mathrm{A}, \mathrm{B}, \mathrm{C}$ & $\mathrm{B}, \mathrm{C}$ & $\mathrm{B}, \mathrm{C}$ & IA \\
\hline $\mathrm{B}$ & 8 & 6 & 8 & 22 & -2 & -2 & & & & & & SSM, Compass IA \\
\hline $\mathrm{C}$ & 4 & 8 & 4 & 16 & 4 & 4 & & & & & & Selfish, IA, SSM \\
\hline \multicolumn{13}{|r|}{ 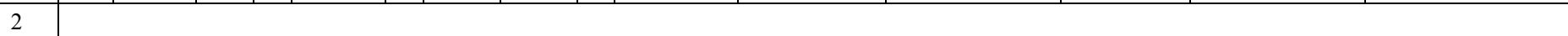 } \\
\hline $\mathrm{A}$ & 4 & 7 & 4 & 15 & 3 & 3 & $\mathrm{~A}$ & $\mathrm{~A}, \mathrm{~B}$ & $\mathrm{~A}, \mathrm{C}$ & $\mathrm{A}, \mathrm{C}$ & $\mathrm{A}, \mathrm{C}$ & Selfish, IA , SSM \\
\hline $\mathrm{B}$ & 8 & 6 & 5 & 19 & -2 & 1 & & & & & & Competitive IA \\
\hline $\mathrm{C}$ & 9 & 6 & 6 & 21 & -3 & 0 & & & & & & SSM, Compass IA \\
\hline \multicolumn{13}{|l|}{3} \\
\hline $\mathrm{A}$ & 10 & 6 & 5 & 21 & -4 & 1 & $\mathrm{~A}, \mathrm{~B}, \mathrm{C}$ & $\mathrm{C}$ & $\mathrm{B}$ & $\mathrm{A}$ & $\mathrm{A}, \mathrm{B}$ & SSM \\
\hline B & 8 & 6 & 6 & 20 & -2 & 0 & & & & & & $\begin{array}{l}\text { Compass SSM, } \\
\text { Compass IA }\end{array}$ \\
\hline $\mathrm{C}$ & 5 & 6 & 5 & 16 & 1 & 1 & & & & & & Competitive IA \\
\hline \multicolumn{13}{|l|}{4} \\
\hline $\mathrm{A}$ & 10 & 6 & 4 & 20 & -4 & 2 & $\mathrm{~A}, \mathrm{~B}, \mathrm{C}$ & $\mathrm{C}$ & $\mathrm{C}$ & $\mathrm{A}$ & $\mathrm{A}, \mathrm{B}$ & SSM \\
\hline $\mathrm{B}$ & 7 & 6 & 6 & 19 & -1 & 0 & & & & & & Compass SSM \\
\hline $\mathrm{C}$ & 6 & 6 & 6 & 18 & 0 & 0 & & & & & & IA \\
\hline \multicolumn{13}{|l|}{5} \\
\hline A & 9 & 7 & 3 & 19 & -2 & 4 & $\mathrm{~A}, \mathrm{~B}, \mathrm{C}$ & $\mathrm{B}$ & A & $\mathrm{C}$ & $\mathrm{A}, \mathrm{C}$ & $\begin{array}{l}\text { Compass SSM, } \\
\text { Compass IA } \\
\end{array}$ \\
\hline $\mathrm{B}$ & 7 & 7 & 1 & 15 & 0 & 6 & & & & & & Competitive IA \\
\hline $\mathrm{C}$ & 11 & 7 & 2 & 20 & -4 & 5 & & & & & & SSM \\
\hline \multicolumn{13}{|l|}{6} \\
\hline A & 6 & 8 & 1 & 15 & 2 & 7 & $\mathrm{~A}$ & $\mathrm{~A}, \mathrm{C}$ & $\mathrm{A}, \mathrm{B}, \mathrm{C}$ & $\mathrm{A}, \mathrm{B}$ & $\mathrm{A}, \mathrm{B}$ & Selfish, IA, SSM \\
\hline $\mathrm{B}$ & 8 & 6 & 7 & 21 & -2 & -1 & & & & & & SSM, Compass IA \\
\hline $\mathrm{C}$ & 6 & 6 & 4 & 16 & 0 & 2 & & & & & & IA \\
\hline \multicolumn{13}{|l|}{7} \\
\hline A & 6 & 10 & 6 & 22 & 4 & 4 & $\mathrm{~A}$ & $\mathrm{~A}, \mathrm{~B}$ & $\mathrm{~A}, \mathrm{~B}$ & $\mathrm{~A}, \mathrm{C}$ & $\mathrm{A}, \mathrm{C}$ & Selfish, IA, SSM \\
\hline $\mathrm{B}$ & 7 & 7 & 7 & 21 & 0 & 0 & & & & & & IA \\
\hline $\mathrm{C}$ & 8 & 7 & 8 & 23 & -1 & -1 & & & & & & SSM \\
\hline \multicolumn{13}{|l|}{8} \\
\hline A & 10 & 5 & 5 & 20 & -5 & 0 & $\mathrm{~A}, \mathrm{~B}, \mathrm{C}$ & $\mathrm{C}$ & $\mathrm{A}, \mathrm{C}$ & $\mathrm{B}$ & $\mathrm{A}, \mathrm{B}$ & $\begin{array}{l}\text { Compass SSM, } \\
\text { Compass IA } \\
\end{array}$ \\
\hline $\mathrm{B}$ & 13 & 5 & 4 & 22 & -8 & 1 & & & & & & SSM \\
\hline $\mathrm{C}$ & 4 & 5 & 4 & 13 & 1 & 1 & & & & & & IA \\
\hline \multicolumn{13}{|l|}{9} \\
\hline $\mathrm{A}$ & 5 & 5 & 5 & 15 & 0 & 0 & $\mathrm{~A}, \mathrm{~B}, \mathrm{C}$ & $\mathrm{A}$ & $\mathrm{A}$ & $\mathrm{B}$ & $\mathrm{B}, \mathrm{C}$ & IA \\
\hline $\mathrm{B}$ & 15 & 5 & 3 & 23 & -10 & 2 & & & & & & SSM \\
\hline $\mathrm{C}$ & 10 & 5 & 5 & 20 & -5 & 0 & & & & & & Compass SSM \\
\hline \multicolumn{13}{|l|}{10} \\
\hline A & 3 & 7 & 3 & 13 & 4 & 4 & $\mathrm{~A}$ & $\mathrm{~A}, \mathrm{~B}$ & $\mathrm{~A}, \mathrm{~B}, \mathrm{C}$ & $\mathrm{A}, \mathrm{C}$ & $\mathrm{A}, \mathrm{C}$ & Selfish, IA, SSM \\
\hline $\mathrm{B}$ & 6 & 6 & 5 & 17 & 0 & 1 & & & & & & IA \\
\hline $\mathrm{C}$ & 9 & 6 & 8 & 23 & -3 & -2 & & & & & & SSM, Compass IA \\
\hline
\end{tabular}


and the $\$ 2$ cost of obtaining either.

A similar comparison can be made for allocation decision 2. The self-interested person will always choose A where own payoff is the highest. Inequality averters may prefer B or C since payoff gaps are lower. Choices $\mathrm{B}$ and $\mathrm{C}$ have the same total inequality but choice $\mathrm{B}$ has person $\mathrm{X}$ receiving $\$ 3$ more than oneself and person $\mathrm{Z}$ receiving the same amount while allocation $\mathrm{C}$ has person $\mathrm{X}$ receiving only $\$ 2$ more and person $\mathrm{Z} \$ 1$ less. Since the competitive inequity averter finds disadvantageous inequality more distasteful than advantageous inequality, he or she would choose B. On the other hand, the compassionate inequity averter will find that C dominates $\mathrm{B}$ because the amount of inequality is the same but the lower income person $\mathrm{Z}$ receives more in $\mathrm{C}$. Both types of social surplus maximizers will find that $\mathrm{C}$ dominates $\mathrm{B}$ since the total payout is higher without reducing payoff to anyone. Again, it is possible for inequity averters and social surplus maximizers to choose the self-interested answer A if their otherregarding preferences are low relative to the cost of obtaining greater equity or social surplus. The rest of the allocation questions are categorized in a similar manner.

Column XIII in Table 1 identifies the categories consistent with each allocation choice, A, B, or C. It is evident from Table 1 that allocation choices are often consistent with more than one type of social preference while each category of preferences is often consistent with more than one allocation choice. This overlap illustrates the perils of trying to identify social preferences by just one or two allocation decisions. Here we analyze each participant's responses to ten questions and the person is identified as falling into one of the categories only if all ten responses are consistent with that type of social preference. This provides a very rigorous test of social preferences of the participants. 
We take self-interest to be the default category; anyone choosing answers consistent with his or her own interest rather than others' in all five questions where there is a self-interested choice is categorized here as self-interested (i.e. $\mathrm{C}$ in question $1, \mathrm{~A}$ in question 2, etc.) Because these individuals have not chosen an other-directed allocation even when there has been small cost to themselves, we cannot reject the hypothesis that they are self-interested. However, it may be that these people are in fact inequity averters or social surplus maximizers but the cost of not acting in their self-interest is too high to pick an alternative allocation or their relative weights on payoffs to others are sufficiently low that they cannot be distinguished from being self-interested. For example, given that they chose the five self-interested allocations, we can conclude that the weight on own payoff is more than eleven times the weight on other's payoff for social surplus maximizers and more than three and a half times the weight on the payoff of those with lower payoff than self for inequity averters. Therefore, we use the other five questions to identify a secondary motivation for those whom we classified as self-interested.

Those who choose one or more non-self-interested allocations are placed in one of the other motivation categories if their answers are consistent. If one's answers are always consistent with competitive inequity aversion (see Table 1), that person is categorized as competitive inequity averse, and similarly, if one's answers are always compassionate inequity averse, that person is identified as strongly compassionate inequity averse. If, however, an individual always answers as an inequity averter, but switches from compassionate to competitive according to the relevant costs, that person is categorized as a weakly compassionate inequity averter since there is at least one instance when he or she acted as a compassionate inequity averter. In such cases, either $\alpha=\beta$ so that the person looks competitive at times and compassionate at other times, or, more likely, inequity aversion is non-linear so that $\alpha$ exceeds $\beta$ 
in some decisions while $\alpha$ is less than $\beta$ for others. For example, when payoff to the worst-off person is low or advantageous inequality is large, $\beta$ may exceed $\alpha$, while if there is large disadvantageous inequality, the opposite may be true. Categorization is similar for social surplus maximizers. Those who always answer as efficiency maximizers are categorized as such and those who always answer compassionately are identified as strongly compassionate social surplus maximizers. However, those who always answer as a social surplus maximizer but switch from efficiency maximization to compassionate are categorized as weakly compassionate social surplus maximizers. Although there are individuals who fail to answer consistently within a given broad category, we are able to classify $65 \%$ of the participants as falling in one of the seven categories.

\section{Classification of Preferences - Empirical Results V.A. Classification of Total Sample}

Table 2 provides the percentage of participants selecting each allocation choice in the ten questions for the total sample and by gender. There is substantial evidence of non-selfish behavior. In the five questions where a selfish choice is possible, between $49 \%$ and $76 \%$ choose an other-regarding allocation. There is a large amount of variation in the answers with only four questions in which one allocation is chosen by more than $50 \%$ of the participants and these are questions where the prices of giving or payoff gaps are particularly large or small. None of the social preference functions appears to dominate preferences by being chosen most often or by being violated least often by the participants under the various prices of giving and payoff gaps 
TABLE 2

Percentages of Participant Responses to Questions

Total Sample and by Gender

\begin{tabular}{|c|c|c|c|c|c|c|c|}
\hline & \multicolumn{3}{|c|}{ Distribution } & \multirow{2}{*}{ TOTAL } & \multirow{2}{*}{ MEN } & \multirow{2}{*}{ WOMEN } & \multirow{2}{*}{ CATEGORY } \\
\hline & $\mathbf{X}$ & YOU & $\mathbf{Z}$ & & & & \\
\hline \multicolumn{8}{|l|}{1} \\
\hline A & 6 & 6 & 5 & 33.8 & 18.8 & 43.3 & IA \\
\hline B & 8 & 6 & 8 & 37.2 & 48.8 & 29.9 & $\begin{array}{l}\text { SSM } \\
\text { Compassion IA }\end{array}$ \\
\hline $\mathrm{C}$ & 4 & 8 & 4 & 29.0 & 32.5 & 26.8 & Selfish, IA, SSM \\
\hline \multicolumn{8}{|r|}{ 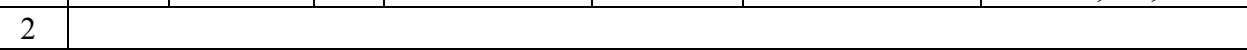 } \\
\hline A & 4 & 7 & 4 & 36.2 & 46.3 & 29.9 & Selfish, IA, SSM \\
\hline $\mathrm{B}$ & 8 & 6 & 5 & 23.2 & 12.5 & 29.9 & Competitive IA \\
\hline $\mathrm{C}$ & 9 & 6 & 6 & 40.6 & 41.3 & 40.2 & $\begin{array}{l}\text { SSM } \\
\text { Compassion IA }\end{array}$ \\
\hline \multicolumn{8}{|r|}{ 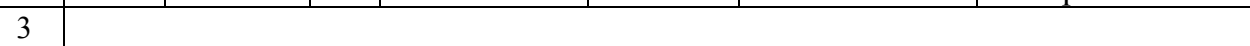 } \\
\hline $\mathrm{A}$ & 10 & 6 & 5 & 41.1 & 46.3 & 37.8 & SSM \\
\hline B & 8 & 6 & 6 & 27.5 & 30.0 & 26.0 & $\begin{array}{l}\text { Compassion SSM } \\
\text { Compassion IA }\end{array}$ \\
\hline $\mathrm{C}$ & 5 & 6 & 5 & 31.4 & 23.8 & 36.2 & Competitive IA \\
\hline \multicolumn{8}{|l|}{4} \\
\hline $\mathrm{A}$ & 10 & 6 & 4 & 28.5 & 35.0 & 24.4 & SSM \\
\hline $\mathrm{B}$ & 7 & 6 & 6 & 24.6 & 33.8 & 18.9 & Compassion SSM \\
\hline $\mathrm{C}$ & 6 & 6 & 6 & 46.9 & 31.3 & 56.7 & IA \\
\hline \multicolumn{8}{|l|}{5} \\
\hline A & 9 & 7 & 3 & 52.2 & 50.0 & 53.5 & $\begin{array}{l}\text { Compassion SSM } \\
\text { Compassion IA }\end{array}$ \\
\hline $\mathrm{B}$ & 7 & 7 & 1 & 13.0 & 12.5 & 13.4 & Competitive IA \\
\hline $\mathrm{C}$ & 11 & 7 & 2 & 34.8 & 37.5 & 33.1 & SSM \\
\hline \multicolumn{8}{|l|}{6} \\
\hline A & 6 & 8 & 1 & 30.9 & 30.0 & 31.5 & Selfish, IA, SSM \\
\hline B & 8 & 6 & 7 & 55.1 & 51.3 & 57.5 & $\begin{array}{l}\text { SSM } \\
\text { Compassion IA }\end{array}$ \\
\hline $\mathrm{C}$ & 6 & 6 & 4 & 14.0 & 18.8 & 11.0 & IA \\
\hline \multicolumn{8}{|l|}{7} \\
\hline A & 6 & 10 & 6 & 51.2 & 55.0 & 48.8 & Selfish, IA, SSM \\
\hline $\mathrm{B}$ & 7 & 7 & 7 & 31.9 & 21.3 & 38.6 & IA \\
\hline $\mathrm{C}$ & 8 & 7 & 8 & 16.9 & 23.8 & 12.6 & SSM \\
\hline \multicolumn{8}{|l|}{8} \\
\hline A & 10 & 5 & 5 & 21.7 & 18.8 & 23.6 & $\begin{array}{l}\text { Compassion SSM } \\
\text { Compassion IA }\end{array}$ \\
\hline $\mathrm{B}$ & 13 & 5 & 4 & 36.2 & 48.8 & 28.3 & SSM \\
\hline $\mathrm{C}$ & 4 & 5 & 4 & 42.0 & 32.5 & 48.0 & IA \\
\hline \multicolumn{8}{|l|}{9} \\
\hline A & 5 & 5 & 5 & 52.7 & 40.0 & 60.6 & IA \\
\hline $\mathrm{B}$ & 15 & 5 & 3 & 27.1 & 37.5 & 20.5 & SWM \\
\hline $\mathrm{C}$ & 10 & 5 & 5 & 20.3 & 22.5 & 18.9 & Compassion SSM \\
\hline \multicolumn{8}{|l|}{10} \\
\hline A & 3 & 7 & 3 & 25.6 & 22.5 & 27.6 & Selfish, IA, SSM \\
\hline $\mathrm{B}$ & 6 & 6 & 5 & 35.7 & 25.0 & 42.5 & IA \\
\hline $\mathrm{C}$ & 9 & 6 & 8 & 38.6 & 52.5 & 29.9 & $\begin{array}{l}\text { SSM } \\
\text { Compassion IA }\end{array}$ \\
\hline
\end{tabular}


in our ten questions. ${ }^{11} 12$ This implies that conclusions as to which social preference function dominates can be sensitive to the particular allocation exercise chosen. For example, testing efficiency maximization (allowing for self-interest) using question 6 would find that only 14\% of answers violate such egocentric efficiency maximization, while questions 3 and 9 (with no selfish choice available) would reveal $59 \%$ and $73 \%$ of answers that are inconsistent with efficiency maximization. Similarly, testing competitive inequity aversion with question 7 (allowing a self-interested choice) reveals that $17 \%$ of answers are inconsistent with inequity aversion while questions 9 and 5 (with no self-interested choice) indicate that $47 \%$ and $87 \%$ of answers respectively are inconsistent with inequity aversion.

These results suggest that social preferences among individuals are heterogeneous. By tracking all ten choices made by each individual we are able both to ascertain whether people are consistent in their choices so that they utilize only one of the postulated preference functions outlined above and to test whether different groups of people have similar social preferences.

Table 3 presents the classification of the respondents using all ten questions of the survey. According to row 4, column 2,34.8\% percent of the sample exhibit inconsistency in their responses or switch between inequity aversion and social surplus maximization in alternative circumstances so that no classification is possible; the other $65.2 \%$ (135 participants) are classifiable. Of these, $13.5 \%$ are classified as self-interested, $27.1 \%$ as inequity averters, and

\footnotetext{
${ }^{11}$ Engelmann and Strobel (2005A) provide a wide variety of allocation exercises to ascertain which type of preference best characterizes decisions. They find that there are some decisions that support each of the motives, there is a large amount of heterogeneity among participants, and most individuals have a mixture of motives.

${ }^{12}$ In our ten questions, pure selfishness is violated by $49 \%$ to $74 \%$ of the choices. Competitive inequity aversion (Fehr and Schmidt's inequity aversion where $\alpha$ exceeds $\beta$ ) is inconsistent with $17 \%$ to $87 \%$ of the choices while compassionate inequity aversion ( $\beta$ exceeds $\alpha$ ) is violated by $17 \%$ to $73 \%$ (in those questions where there is an allocation inconsistent with it.)

Compassionate social surplus maximizing (also Cox and Sadiraj's egocentric altruism and Engelmann and Strobel's generalized quasi-maximin preferences with positive weights) is violated in $13 \%$ to $61 \%$ of choices in the questions while egocentric efficiency maximizing is inconsistent with $14 \%$ to $73 \%$ of answers. In addition, pure envy (Engelmann and Strobel's quasimaximin preferences with negative weights) is violated by $46 \%$ to $87 \%$ of the choices (in questions where there was not a selfish allocation) and maximin is violated by $14 \%$ to $78 \%$.
} 
Table 3

\section{Categorization of Participants' Preferences \\ Total Sample and by Gender \\ (frequencies in parentheses)}

\begin{tabular}{|c|c|c|c|}
\hline Percent of sample classified as: & $\begin{array}{c}\text { Total } \\
\text { (1) }\end{array}$ & $\begin{array}{c}\text { Male } \\
(2)\end{array}$ & $\begin{array}{c}\text { Female } \\
\text { (3) }\end{array}$ \\
\hline 1. Self-interested & $\begin{array}{c}13.5 \% \\
(28)\end{array}$ & $\begin{array}{c}17.5 \% \\
(14) \\
\end{array}$ & $\begin{array}{c}11.0 \% \\
(14)\end{array}$ \\
\hline 2. Inequity Averse (IA) & $\begin{array}{l}27.1 \% \\
(56)\end{array}$ & $\begin{array}{l}10.0 \% * * * \\
(8)\end{array}$ & $\begin{array}{c}37.8 \% \\
(48)\end{array}$ \\
\hline 2A. Competitive IA & $\begin{array}{l}3.4 \% \\
(7)\end{array}$ & $\begin{array}{l}2.5 \% \\
(2)\end{array}$ & $\begin{array}{l}3.9 \% \\
(5)\end{array}$ \\
\hline 2B. Strongly Compassionate IA & $\begin{array}{l}3.9 \% \\
(8)\end{array}$ & $\begin{array}{c}3.8 \% \\
(3)\end{array}$ & $\begin{array}{l}3.9 \% \\
(5)\end{array}$ \\
\hline 2C. Weakly Compassionate IA & $\begin{array}{c}19.8 \% \\
(41)\end{array}$ & $\begin{array}{l}3.8 \% * * * \\
(3)\end{array}$ & $\begin{array}{c}29.9 \% \\
(38)\end{array}$ \\
\hline $\begin{array}{l}\text { 3. Social Surplus } \\
\text { Maximizing (SSM) }\end{array}$ & $\begin{array}{l}24.6 \% \\
(51)\end{array}$ & $\begin{array}{c}37.5 \% * * * \\
(30)\end{array}$ & $\begin{array}{c}16.5 \% \\
(21)\end{array}$ \\
\hline 3A. Efficiency Maximizing & $\begin{array}{c}10.1 \% \\
(21)\end{array}$ & $\begin{array}{c}12.5 \% \\
(10)\end{array}$ & $\begin{array}{l}8.7 \% \\
(11)\end{array}$ \\
\hline 3B. Strongly Compassionate SSM & $\begin{array}{l}3.4 \% \\
(7)\end{array}$ & $\begin{array}{l}5.0 \% \\
(4)\end{array}$ & $\begin{array}{l}2.4 \% \\
(3)\end{array}$ \\
\hline 3C. Weakly Compassionate SSM & $\begin{array}{c}11.1 \% \\
(23)\end{array}$ & $\begin{array}{c}20.0 \% * * * \\
(16)\end{array}$ & $\begin{array}{l}5.5 \% \\
(7)\end{array}$ \\
\hline 4. Unable to Classify & $\begin{array}{l}34.8 \% \\
(72)\end{array}$ & $\begin{array}{c}35.0 \% \\
(28)\end{array}$ & $\begin{array}{l}34.6 \% \\
(44)\end{array}$ \\
\hline Total & $\begin{array}{l}100 \% \\
(207)\end{array}$ & $\begin{array}{c}100 \% \\
(80)\end{array}$ & $\begin{array}{l}100 \% \\
(127)\end{array}$ \\
\hline
\end{tabular}


$24.6 \%$ as social surplus maximizers. These numbers signify that a strong majority ( $86.5 \%)$ of the respondents exhibit non-self-interested behavior in one or more allocation decisions and, of the other-regarding participants who can be classified, roughly half consistently act as social surplus maximizers and the other half consistently act as inequity averters. ${ }^{13}$

Within the general categories, people separate into the more specific categories. Of the 56 inequity averters identified in row 2,7 or $3.4 \%$ of the sample are consistently competitive inequity averters, 8 or $3.9 \%$ of the sample are strongly compassionate, and 41 or $19.8 \%$ are weakly compassionate as they switch from compassionate to competitive according to the terms of the allocation. Of the 51 social surplus maximizers identified in row 3 less than half ( 21 or $10.1 \%$ of the sample) are efficiency maximizers. The remaining social surplus maximizers are split between 7 who are strongly compassionate and 23 who are weakly compassionate. ${ }^{14}$ The categorizations show that a larger fraction of inequity averters than social surplus maximizers fall into one of the compassionate subcategories ( 49 of the 56 inequity averters or $87.5 \%$ and 30 of 51 social surplus maximizers or $58.8 \%$ ) and this difference is significant at the 0.01 level.

The respondents themselves generally agree with our categorization. Question 12 of the survey asks them to identify the motivations that guided their decisions. $89 \%$ of the selfinterested respondents identified motive A, "give myself as much as possible" as the most

\footnotetext{
${ }^{13}$ For those who are identified as self-interested by their answers to questions $1,2,6,7$, and 10, we can identify a secondary motivation if their answers to the other five questions are consistent. Of the 28 self-interested respondents, $64.3 \%$ can be classified with a secondary motivation; 9 (32.1\% of self interested) are secondarily inequity averters and 9 (32.1\% of self interested) are social surplus maximizers implying that the self-interested are equally likely to have secondary motivations consistent with social surplus maximization and inequity aversion.

${ }^{14}$ Among the nine self-interested respondents whose secondary motive is inequity aversion, 6 are competitive and 3 are weakly compassionate. The self-interested respondents whose secondary motive is social surplus maximization, however, are predominately efficiency maximizers rather than compassionate (8 compared to 1$)$. While 79 of the $107(73.8 \%)$ who are categorized as inequity averse or social surplus maximizing are weakly or strongly compassionate, only 4 of the 18 (22.2\%) self-interested have a secondary compassionate classification.
} 
prominent motive in their behavior, $82 \%$ of inequity averters identified motive $\mathrm{B}$, "create an equitable distribution" as their most important motive, and $62.7 \%$ of the social surplus maximizers identified either motive $\mathrm{D}$, "make the total sum of money paid out as large as possible" or motive F, "give to others when the opportunity is available" as their most important motive. Looking within the more specific classifications, only the strongly compassionate social surplus maximizers fall below $50 \%$ in articulating preferences consistent with our categorization, primarily because about forty percent of these individuals identify "creating an equitable distribution" as their most important motive. When looking at the top three self-identified motivations, these percentages increase markedly, with more than $95 \%$ percent of each category, both broad and narrow, identifying motivations which are the same as classified by the allocation experiment. This strong correlation between participants' stated motivations and our categorizations supports the validity of our classifications based on the allocation decisions in the experiments.

The results presented in column 1 of Table 3 make three important points. First, there is considerable other-regarding behavior by subjects with only $13.5 \%$ choosing the self-interested allocation every time there was possible gain to self, implying that $86.5 \%$ of the participants made at least one non-selfish allocation decision. Second, of those participants exhibiting otherregarding behavior, about half are motivated by inequity aversion and half are motivated by social surplus maximization. A similar ratio results within the secondary classifications of those who were primarily self-interested. Finally, compassion for those less well-off does drive the behavior of many subjects with 7.3\% (15) categorized as strongly compassionate, either as inequity averters or social surplus maximizers, and another $30.9 \%$ (64) categorized as weakly compassionate by choosing one or more allocation that is compassionate. These 79 individuals 
represent $58.5 \%$ of the 135 who can be categorized. Concern for those less well-off leads a strong majority of inequity averters $(87.5 \%)$ to accept more disadvantageous inequity or more total inequality and a majority of social surplus maximizers $(58.8 \%)$ to choose a lower total payoff in order to benefit those who are the worst-off.

\section{V.B. Categorization by Gender}

Columns 2 and 3 of Table 3 provide the categorization of preferences broken down by gender. The same percentage of men and women are classifiable (65\% in row 4), indicating that their preferences are consistent in the ten questions. However, the categorizations reveal significant gender differences in preferences: men are much more likely to be selfish or social surplus maximizers and women are much more likely to be inequity averters. While $17.5 \%$ of men are classified as self-interested, only $11.0 \%$ of women fall into this category, although the difference is not significant. On the other hand, women (37.8\%) are almost four times as likely to be classified as inequity averters as men $(10.0 \%)$, while men $(37.5 \%)$ are twice as likely as women $(16.5 \%)$ to be social surplus maximizers. For both categories, the gender differences are statistically significant.

Within the category of inequity averters, most women (29.9\% of the $37.8 \%$ inequity averters) are categorized as weakly compassionate inequity averters, indicating that they switch between competitive and compassionate inequity aversion, while male inequity averters are more evenly split between the three subcategories. Of social surplus maximizers, while women are roughly half efficiency maximizers and half either strongly or weakly compassionate (9\% and 
$8 \%$ respectively), men are twice as often compassionate (either strongly or weakly) as efficiency maximizing (25\% compared to $13 \%) .{ }^{15}$

Comparing compassion between women and men, we find that 53 women $(63.9 \%$ of those that can be classified) and 26 men (50.0\%) are either weakly or strongly compassionate. These differences are significant only at $\mathrm{p}$ values of 0.185 .

\section{V.C. Categorization by Major}

Table 4 gives the breakdown of category by major. The majors are differentiated by business, economics, and other major, and social preferences do seem to differ by major. Business majors are more often self-interested (17\%) than economics and other majors (12\% each) but the differences are not significant. Business majors are significantly less likely to be inequity averters than other majors with roughly $17 \%$ of business majors being classified as inequity averters and $35 \%$ of other majors falling into this category. Within the inequity aversion classification, business majors are significantly less likely to be weakly compassionate inequity averters than other majors as well. Although economics majors are also less likely than other majors to be inequity averters generally and weakly compassionate inequity averters more specifically, the differences are not statistically significant.

Economics majors are significantly more likely to be social surplus maximizers (36\%) than other majors (19.8\%). Business majors are also more often social surplus maximizers

\footnotetext{
${ }^{15}$ The secondary motives of self-interested respondents show that self-interested individuals are split up between the secondary motives in different ways for men and women. Self-interested women are inconsistent in their responses so that $57 \%$ are unclassifiable while only $14 \%$ of men cannot be classified. Of the women who can be categorized, twice as many are social surplus maximizers as inequity averters, in marked contrast to women who are not selfinterested, who are inequity averters more than twice as often as social surplus maximizers. On the other hand, selfinterested men are more likely to be inequity averse (50\%) than social surplus maximizing (36\%) in their secondary motivation. Within categories, both self-interested men and women are competitive or efficiency maximizing; only $7 \%$ of men and $21 \%$ of women have a secondary classification that is compassionate.
} 
Table 4

Categorization of Participants' Preferences by Major

(frequencies in parentheses)

\begin{tabular}{|c|c|c|c|c|}
\hline Percent of sample classified as: & $\begin{array}{l}\text { Total } \\
\text { (1) }\end{array}$ & $\begin{array}{l}\text { Economics } \\
\text { Major } \\
\text { (2) }\end{array}$ & $\begin{array}{c}\text { Business } \\
\text { Major } \\
\text { (3) }\end{array}$ & $\begin{array}{l}\text { Other } \\
\text { Major } \\
\text { (4) }\end{array}$ \\
\hline 1. Self-interested & $\begin{array}{c}13.5 \% \\
(28)\end{array}$ & $\begin{array}{c}12.0 \% \\
(3)\end{array}$ & $\begin{array}{c}16.9 \% \\
(12)\end{array}$ & $\begin{array}{c}11.7 \% \\
(13)\end{array}$ \\
\hline 2. Inequity Averse (IA) & $\begin{array}{c}27.1 \% \\
(56)\end{array}$ & $\begin{array}{c}20.0 \% \\
(5)\end{array}$ & $\begin{array}{c}16.9 \% * * \\
(12)\end{array}$ & $\begin{array}{c}35.1 \% \\
(39)\end{array}$ \\
\hline 2a. Competitive IA & $\begin{array}{l}3.4 \% \\
(7)\end{array}$ & $\begin{array}{l}0 \% \\
(0)\end{array}$ & $\begin{array}{c}2.8 \% \\
(2)\end{array}$ & $\begin{array}{c}4.5 \% \\
(5)\end{array}$ \\
\hline 2b. Strongly Compassionate IA & $\begin{array}{l}3.9 \% \\
(8)\end{array}$ & $\begin{array}{l}4.0 \% \\
(1)\end{array}$ & $\begin{array}{l}2.8 \% \\
(2)\end{array}$ & $\begin{array}{l}4.5 \% \\
(5)\end{array}$ \\
\hline 2c. Weakly Compassionate IA & $\begin{array}{c}19.8 \% \\
(41)\end{array}$ & $\begin{array}{l}16.0 \% \\
(4)\end{array}$ & $\begin{array}{c}11.3 \% * * \\
(8)\end{array}$ & $\begin{array}{l}26.1 \% \\
(29)\end{array}$ \\
\hline $\begin{array}{l}\text { 3. Social Surplus Maximizing } \\
\text { (SSM) }\end{array}$ & $\begin{array}{c}24.6 \% \\
(51)\end{array}$ & $\begin{array}{l}36.0 \%+ \\
\text { (9) }\end{array}$ & $\begin{array}{c}28.2 \% \\
(20)\end{array}$ & $\begin{array}{l}19.8 \% \\
(22)\end{array}$ \\
\hline 3a. Efficiency Maximizing & $\begin{array}{c}10.1 \% \\
(21)\end{array}$ & $\begin{array}{c}4.0 \% \\
(1)\end{array}$ & $\begin{array}{c}16.9 \% * * \\
(12)\end{array}$ & $\begin{array}{c}7.2 \% \\
(8) \\
\end{array}$ \\
\hline 3b. Strongly Compassionate SSM & $\begin{array}{c}3.4 \% \\
(7)\end{array}$ & $\begin{array}{c}4.0 \% \\
(1)\end{array}$ & $\begin{array}{c}2.8 \% \\
(2)\end{array}$ & $\begin{array}{l}3.6 \% \\
(4)\end{array}$ \\
\hline 3c. Weakly Compassionate SSM & $\begin{array}{c}11.1 \% \\
(23)\end{array}$ & $\begin{array}{c}28.0 \%++ \\
(7)\end{array}$ & $\begin{array}{c}8.5 \% \\
(6)\end{array}$ & $\begin{array}{l}9.0 \% \\
(10) \\
\end{array}$ \\
\hline Unable to Classify & $\begin{array}{c}34.8 \% \\
(72)\end{array}$ & $\begin{array}{l}32.0 \% \\
(8)\end{array}$ & $\begin{array}{l}38.0 \% \\
(27)\end{array}$ & $\begin{array}{c}33.3 \% \\
(37)\end{array}$ \\
\hline Total & $\begin{array}{l}100 \% \\
(207)\end{array}$ & $\begin{array}{l}100 \% \\
(25)\end{array}$ & $\begin{array}{c}100 \% \\
(71)\end{array}$ & $\begin{array}{c}100 \% \\
(111)\end{array}$ \\
\hline \multicolumn{5}{|c|}{$\begin{array}{l}\text { ** The business majors' percentage is significantly different than the other majors' percentage at the } 0.05 \text { level. } \\
* \text { The business majors' percentage is significantly different than the other majors' percentage at the } 0.10 \text { level. } \\
++ \text { The economics majors' percentage is significantly different than other majors' percentage at the } 0.05 \text { level. } \\
+ \text { The economics majors' percentage is significantly different than other majors' percentage at the } 0.10 \text { level. }\end{array}$} \\
\hline
\end{tabular}


(28\%), but the difference is not significant. At the same time, business majors $(17 \%)$ are the group most likely to be efficiency maximizers. While this difference is significant when compared to other majors $(7 \%)$, it is only significant at the 0.11 level when compared to economics majors (4\%). Within the social surplus maximization category, economics majors are much more likely to be compassionate social surplus maximizers than efficiency maximizers $(8$ compared to 1) while business social surplus maximizers are more often efficiency maximizers than compassionate, with only 8 of 20 business social surplus maximizers categorized as compassionate. Finally, within the self-interested category, business majors are more likely to be self-interested with an efficiency maximization secondary categorization than other majors and than economics majors.

Compassion appears to differ among the majors. Of those who can be categorized, 18 (41\%) of business majors, $13(76 \%)$ of economics majors, and $48(65 \%)$ of other majors fall into one of the four compassionate categories. This difference in compassion between business majors and both economics and other majors is significantly different from zero at the 0.01 level.

\section{V.D. Probit Analysis}

The extent to which demographic characteristics affect motivation categorization is further explored with the use of probit analysis. We estimate separate probit equations where the dependent variable is a dummy variable representing a specific categorization; these dummies include the seven categories and the aggregated categories of inequity averter, social welfare maximizer, and two categories of compassion, one that includes all 4 types of compassion (weakly and strongly compassionate inequity averters and weakly and strongly compassionate 
social welfare maximizers) and one that includes the two weakly compassionate categories ${ }^{16}$ Independent variables include dummy variables for gender, practicing a religion, business major, economics major, and a high family income category ( above $\$ 150,000$ ). The results for the probits are presented in Table 5. Since all the independent variables are dummies, a reported value gives the change in the probability of being classified with a given motivation if the respondent has the characteristic identified by the dummy variable rather than not having that characteristic.

The probits substantiate the finding that gender is an important predictor of classification type of preferences. Being female decreases the probability of being a social welfare maximizer by 19 percentage points (row 3) but increases the probability of being inequity averse by 27 percentage points (row 2). Within categories, being female also increases the probability of being a weakly compassionate inequity averter by 26 (row 2c) percentage points and decreases the probability of being a weakly compassionate social welfare maximizer by 13 (row 3c) percentage points. Other demographic characteristics have little impact on categorization, with the exception of college major. Being a business major significantly decreases the probability of being an inequity averter by 13 percentage points (row 2) and significantly increases the probability of being an efficiency maximizer by 9 percentage points (row 3a). Also, practicing a religion reduces the probability of being a strongly compassionate inequity averter by 5 percentage points (row $2 \mathrm{~b}$ ) but increases the probability of being a strongly compassionate social welfare maximizer by 4 percentage points $(p=0.14)$. Focusing on the aggregated compassionate

\footnotetext{
${ }^{16}$ We also performed the analysis with a multinomial logit estimation where each category is simultaneously specified as a potential classification. The multinomial logit suffers from the fact that coefficients will differ according to which category is the comparison category, thus complicating interpretation and exposition. Two category probits give a more intuitive interpretation. The logits, however, give comparable results in which gender is the most important predictor of category.
} 
Table 5

Change in Probability of Being a Type by Subject Characteristics (Derived from Probit Equations and p-values in parentheses.)

\begin{tabular}{|c|c|c|c|c|c|c|}
\hline & $\begin{array}{c}1 \\
\text { Female }\end{array}$ & $\begin{array}{c}2 \\
\text { Business } \\
\text { Major }\end{array}$ & $\begin{array}{c}3 . \\
\text { Economics } \\
\text { Major }\end{array}$ & $\begin{array}{c}4 . \\
\text { Practicing } \\
\text { Religion }\end{array}$ & $\begin{array}{c}5 . \\
\text { High } \\
\text { Income }\end{array}$ & $\begin{array}{c}6 . \\
\text { Pseudo } \\
\text { R }^{2}\end{array}$ \\
\hline 1. Self-Interested & $\begin{array}{l}-0.619 \\
(0.237) \\
\end{array}$ & $\begin{array}{c}0.050 \\
(0.372) \\
\end{array}$ & $\begin{array}{l}-0.014 \\
(0.865) \\
\end{array}$ & $\begin{array}{l}-0.019 \\
(0.704) \\
\end{array}$ & $\begin{array}{c}0.007 \\
(0.885)\end{array}$ & 0.018 \\
\hline 2. Inequity Averse (IA) & $\begin{array}{c}0.270 * * * \\
(0.000)\end{array}$ & $\begin{array}{l}-0.126^{*} \\
(0.074)\end{array}$ & $\begin{array}{l}-0.010 \\
(0.924) \\
\end{array}$ & $\begin{array}{l}-0.014 \\
(0.830)\end{array}$ & $\begin{array}{l}-0.055 \\
(0.387)\end{array}$ & 0.110 \\
\hline 2a.Competitive IA & $\begin{array}{c}0.007 \\
(0.817) \\
\end{array}$ & $\begin{array}{l}-0.013 \\
(0.691) \\
\end{array}$ & dropped & $\begin{array}{l}-0.000 \\
(0.993)\end{array}$ & $\begin{array}{l}-0.005 \\
(0.853)\end{array}$ & 0.006 \\
\hline $\begin{array}{l}\text { 2b.Strongly } \\
\text { Compassionate IA }\end{array}$ & $\begin{array}{l}-0.001 \\
(0.975) \\
\end{array}$ & $\begin{array}{l}-0.017 \\
(0.491) \\
\end{array}$ & $\begin{array}{c}0.007 \\
(0.868) \\
\end{array}$ & $\begin{array}{c}-0.055^{* *} \\
(0.055)\end{array}$ & $\begin{array}{c}0.024 \\
(0.322)\end{array}$ & 0.079 \\
\hline $\begin{array}{l}\text { 2c.Weakly } \\
\text { Compassionate IA }\end{array}$ & $\begin{array}{c}0.262 * * * \\
(0.000)\end{array}$ & $\begin{array}{l}-0.076 \\
(0.194)\end{array}$ & $\begin{array}{c}0.039 \\
(0.681)\end{array}$ & $\begin{array}{c}0.044 \\
(0.403)\end{array}$ & $\begin{array}{l}-0.074 \\
(0.157)\end{array}$ & 0.157 \\
\hline $\begin{array}{l}\text { 3. Social Welfare } \\
\text { Maximizer (SWM) }\end{array}$ & $\begin{array}{c}-0.188^{* * *} \\
(0.005)\end{array}$ & $\begin{array}{c}0.066 \\
(0.361) \\
\end{array}$ & $\begin{array}{c}0.087 \\
(0.412) \\
\end{array}$ & $\begin{array}{c}0.007 \\
(0.915) \\
\end{array}$ & $\begin{array}{l}-0.023 \\
(0.711)\end{array}$ & 0.054 \\
\hline $\begin{array}{l}\text { 3a. Efficiency } \\
\text { Maximizer }\end{array}$ & $\begin{array}{l}-0.028 \\
(0.523) \\
\end{array}$ & $\begin{array}{l}0.088 * \\
(0.073)\end{array}$ & $\begin{array}{l}-0.043 \\
(0.553) \\
\end{array}$ & $\begin{array}{l}-0.048 \\
(0.257) \\
\end{array}$ & $\begin{array}{c}0.009 \\
(0.831)\end{array}$ & 0.059 \\
\hline $\begin{array}{l}\text { 3b.Strongly } \\
\text { Compassionate SWM }\end{array}$ & $\begin{array}{l}-0.025 \\
(0.306) \\
\end{array}$ & $\begin{array}{c}0.000 \\
(0.994) \\
\end{array}$ & $\begin{array}{l}-0.006 \\
(0.842)\end{array}$ & $\begin{array}{c}0.037 \\
(0.140) \\
\end{array}$ & $\begin{array}{l}-0.023 \\
(0.301)\end{array}$ & 0.082 \\
\hline $\begin{array}{l}\text { 3c.Weakly } \\
\text { Compassionate SWM }\end{array}$ & $\begin{array}{c}-0.129 * * * \\
(0.010)\end{array}$ & $\begin{array}{l}-0.029 \\
(0.555)\end{array}$ & $\begin{array}{c}0.101 \\
(0.174) \\
\end{array}$ & $\begin{array}{c}0.015 \\
(0.720) \\
\end{array}$ & $\begin{array}{c}0.001 \\
(0.983)\end{array}$ & 0.095 \\
\hline $\begin{array}{l}\text { 4. Compassionate. } \\
\text { (weakly }+ \text { strongly) }\end{array}$ & $\begin{array}{c}0.104 \\
(0.168) \\
\end{array}$ & $\begin{array}{l}-0.142 * \\
(0.075) \\
\end{array}$ & $\begin{array}{c}0.152 \\
(0.195) \\
\end{array}$ & $\begin{array}{c}0.047 \\
(0.515) \\
\end{array}$ & $\begin{array}{l}-0.074 \\
(0.299)\end{array}$ & 0.043 \\
\hline 4a. Weakly Compassionate & $\begin{array}{l}0.134^{*} \\
(0.062)\end{array}$ & $\begin{array}{l}-0.112 \\
(0.141)\end{array}$ & $\begin{array}{c}0.166 \\
(0.145)\end{array}$ & $\begin{array}{c}0.064 \\
(0.345)\end{array}$ & $\begin{array}{l}-0.071 \\
(0.264)\end{array}$ & 0.052 \\
\hline
\end{tabular}


category, business majors have a 14\% lower probability than other majors of being

compassionate (row 4) and women are $13 \%$ more likely than men to be weakly compassionate

(row $4 \mathrm{a}$ ). On the other hand the probability of being self-interested does not differ among the groups examined.

\section{Responses to Changing Incentives}

In order to evaluate how individuals respond to different costs of other-directed economic decisions and to the degree of inequality, we categorize the participants according to their answers on the first four questions that provide moderate costs and payoff gaps. ${ }^{17}$ We then compare individuals' answers to the other six questions where costs and inequality gaps are different. This exercise also provides information on the consistency of people's choices and whether they switch motivation categories. Table 6 presents the categorization according to the first four questions for the full sample and separated by gender. As would be expected, with a smaller number of questions and with less variation in cost and payoff gaps, more individuals are consistent in their answers so that we can place $81.6 \%$ (compared to $65.2 \%$ ) in one of the categories.

The four-question categorization finds more participants to be self-interested than the tenquestion classification, $22.7 \%$ compared to $13.5 \%$. In order to be classified as self-interested in the four-question classification, only two questions must be answered selfishly while the selfinterested allocation must be chosen in all of five possible questions in the ten-question classification. In addition, the ten-question categorization has some self-interested allocations with a relatively low cost of being other-directed and large payoff gaps, both of which may cause

\footnotetext{
${ }^{17}$ We tried a few other four question combinations to categorize individuals and compared the resulting categorizations to stated motives. We found the question 1 to 4 categorization to be most consistent with stated motives; $79 \%$ of selfish, $85 \%$ of inequity averters, and $70 \%$ of social surplus maximizers self-identify their strongest motive as the one exactly in line with our categorization.
} 
Table 6

Categorization of Participants' Preferences

Total Sample and by Gender Using the First Four Questions

(frequencies in parentheses)

\begin{tabular}{|c|c|c|c|}
\hline Percent of sample classified as: & $\begin{array}{l}\text { Total } \\
\text { (1) }\end{array}$ & $\begin{array}{l}\text { Male } \\
\text { (2) }\end{array}$ & $\begin{array}{c}\text { Female } \\
\text { (3) }\end{array}$ \\
\hline 1. Self-interested & $\begin{array}{c}22.7 \% \\
(47)\end{array}$ & $\begin{array}{c}31.3 \% * * * \\
(25)\end{array}$ & $\begin{array}{c}17.3 \% \\
(22)\end{array}$ \\
\hline 2. Inequity Averse (IA) & $\begin{array}{c}30.9 \% \\
(64)\end{array}$ & $\begin{array}{c}11.3 \% * * * \\
(9)\end{array}$ & $\begin{array}{c}43.4 \% \\
(55)\end{array}$ \\
\hline 2A. Competitive IA & $\begin{array}{c}13.5 \% \\
(28)\end{array}$ & $\begin{array}{c}1.3 \% * * * \\
(1)\end{array}$ & $\begin{array}{c}21.3 \% \\
(27)\end{array}$ \\
\hline 2B. Strongly Compassionate IA & $\begin{array}{l}6.8 \% \\
(14)\end{array}$ & $\begin{array}{c}2.5 \% * * \\
(2)\end{array}$ & $\begin{array}{l}9.5 \% \\
(12)\end{array}$ \\
\hline 2C. Weakly Compassionate IA & $\begin{array}{c}10.6 \% \\
(22)\end{array}$ & $\begin{array}{c}7.5 \% \\
(6)\end{array}$ & $\begin{array}{c}12.6 \% \\
(16)\end{array}$ \\
\hline $\begin{array}{l}\text { 3. Social Surplus } \\
\text { Maximizing (SSM) }\end{array}$ & $\begin{array}{c}28.0 \% \\
(58)\end{array}$ & $\begin{array}{c}38.8 \% * * * \\
(31)\end{array}$ & $\begin{array}{c}21.3 \% \\
(27)\end{array}$ \\
\hline 3A. Efficiency Maximizing & $\begin{array}{c}15.0 \% \\
(31)\end{array}$ & $\begin{array}{c}15.0 \% \\
(12)\end{array}$ & $\begin{array}{c}15.0 \% \\
(19)\end{array}$ \\
\hline 3B. Strongly Compassionate SSM & $\begin{array}{l}7.7 \% \\
(16)\end{array}$ & $\begin{array}{c}15.0 \% * * * \\
(12)\end{array}$ & $\begin{array}{c}3.1 \% \\
(4)\end{array}$ \\
\hline 3C. Weakly Compassionate SSM & $\begin{array}{l}5.3 \% \\
(11)\end{array}$ & $\begin{array}{c}8.8 \% \\
(7)\end{array}$ & $\begin{array}{c}3.1 \% \\
(4)\end{array}$ \\
\hline 4. Unable to Classify & $\begin{array}{c}18.4 \% \\
(38)\end{array}$ & $\begin{array}{c}18.8 \% \\
(15)\end{array}$ & $\begin{array}{c}18.1 \% \\
(23)\end{array}$ \\
\hline Total & $\begin{array}{l}100 \% \\
(207)\end{array}$ & $\begin{array}{c}100 \% \\
(80)\end{array}$ & $\begin{array}{c}100 \% \\
(127)\end{array}$ \\
\hline \multicolumn{4}{|c|}{$\begin{array}{l}* * * \text { The male percentage is significantly different than the female percentage at the } 0.01 \text { level. } \\
* * \text { The male percentage is significantly different than the female percentage at the } 0.05 \text { level. } \\
* \quad \text { The male percentage is significantly different than the female percentage at the } 0.10 \text { level. }\end{array}$} \\
\hline
\end{tabular}


some participants to choose a non-selfish decision. The percentages that are inequity averters and social welfare maximizers rise slightly, from $27.1 \%$ to $30.9 \%$ for the former and from $24.6 \%$ to $28.0 \%$ for the latter, but again, the split is about even between the two. Within the inequity averse category, with fewer questions, there is more consistency in answers so the percentage who are weakly compassionate declines from $19.8 \%$ to $10.6 \%$, while those who are competitive inequity averse increases from $3.4 \%$ to $13.5 \%$ and those who are strongly compassionate rises from $3.9 \%$ to $6.8 \%$. Within the social surplus maximizing category, weakly compassionate declines from $11.1 \%$ to $5.3 \%$, strongly compassionate rises from $3.4 \%$ to $7.7 \%$, and efficiency maximizers increase from $10.1 \%$ to $15.0 \%{ }^{18}$ Columns 2 and 3 provide the categorizations broken down by gender. While the gender differences are similar to those found in the classifications using all ten questions, there are some differences. In the four-question classification, men are significantly more likely to be self-interested than women $(31.3 \%$ compared to $17.3 \%$ ). While the gender differences in inequity aversion are about the same with women four times more likely than men to be inequity averters, in this classification women are far more likely to be competitive inequity averse, with $21.3 \%$ in this category compared to $3.9 \%$ using all 10 questions. Therefore, the four-question categorization with relatively moderate payoff gaps and costs of being other-directed results in more competitive choices by women. On the other hand, additional questions which increase payoff gaps and lower costs motivate women to be more compassionate, since most are weakly compassionate inequity averters in the tenquestion classification. There is little change in men's classification as social surplus

\footnotetext{
${ }^{18}$ The secondary motivation of those classified as self-interested (not displayed) is more often social surplus maximizing than inequity averting (46.8\% compared to $38.3 \%$ ), while they were evenly split in the ten-question categorization (32.1\% each). Among those who are at first self-interested, secondary motives of inequity aversion and efficiency maximization dominate compassion.
} 
maximizers, but women are slightly more often classified as social surplus maximizers in the four question categorization ( $21.3 \%$ compared to $16.5 \%)$ and twice as many are efficiency maximizers as compassionate social surplus maximizers $(15.0 \%$ compared to $6.2 \%)$ whereas they were evenly split in the original classification.

\section{VI.A. Are people more self-interested when the cost of being unselfish is high?}

Given the hypothesized utility functions of those individuals who value other-regarding behavior, individuals are expected to make more allocation decisions that are self-interested as being unselfish becomes more expensive. To determine whether the subjects respond to these changing incentives, we compare the responses to questions 1, 7, and 10. All three questions have a self-interested response where the respondent will get more for himself or herself by picking this choice. While the payoff gaps (representing the degree of inequality) for the selfinterested choice are the same in all three questions ( $\$ 4$ more than each of the other two people), the costs of making an unselfish choice differ. The returns to self-interestedness and the prices of being unselfish are presented in Table 7 rows 1 to 4 . According to row 1, by picking the selfinterested choice, the respondent gains $\$ 1$ in question 10, \$2 in question 1, and \$3 in question 7 . The relative price of giving depends on which allocation is chosen. In question 10, the individual gives up $\$ 1$ by choosing $B$ and the others gain $\$ 5$ so the relative price of giving is $\$ 0.20$, while if $\mathrm{C}$ is chosen, $\$ 1$ is given up but others gain $\$ 11$, providing a relative price of giving of $\$ 0.09$ (row 2, column 2). Similarly, for question 1, the relative price of giving is $\$ 0.67$ for $\mathrm{A}$ and $\$ 0.25$ for $\mathrm{B}$ and for question 7 it is $\$ 1.50$ for $\mathrm{B}$ and $\$ 0.75$ for $\mathrm{C}$. We also calculate the price of equity, defined to be the amount given up to decrease the payoff gap by $\$ 1$. In question 10, the person who chooses the inequity averse choice B loses a dollar but reduces payoff gaps by $\$ 7$, so the cost of a dollar of equity is $\$ 0.14$ (row 3 column 2). Similarly, the cost of choosing 
Table 7

Relationship Between Percentage Picking Self-interested Choice and Measures of Prices of Unselfish Decisions

\begin{tabular}{|c|c|c|c|c|c|c|}
\hline \multicolumn{7}{|c|}{ Allocation Choices } \\
\hline & \multicolumn{2}{|c|}{ Question 10} & \multicolumn{2}{|c|}{ Question 1 } & \multicolumn{2}{|c|}{ Question 7} \\
\hline & $\mathbf{X} \mathbf{Y Z}$ & $\begin{array}{l}\text { Total } \\
\text { Payoff }\end{array}$ & $\mathbf{X ~ Y ~ Z ~}$ & $\begin{array}{l}\text { Total } \\
\text { Payoff }\end{array}$ & $\mathbf{X} \mathbf{Y} \mathbf{Z}$ & $\begin{array}{c}\text { Total } \\
\text { Payoff }\end{array}$ \\
\hline $\mathbf{A}$ & $373^{\mathrm{a}}$ & 13 & 665 & 17 & $6106^{\mathrm{a}}$ & 22 \\
\hline $\mathbf{B}$ & 665 & 17 & 868 & 22 & 777 & 21 \\
\hline $\mathbf{C}$ & 968 & 23 & $484^{\mathrm{a}}$ & 16 & 878 & 23 \\
\hline \multicolumn{7}{|c|}{$\begin{array}{l}\text { Alternative Prices of Being Unselfish } \\
\text { and Percentage Choosing Self-interested Allocation }\end{array}$} \\
\hline (1) & \multicolumn{2}{|c|}{ (2) Question 10} & \multicolumn{2}{|c|}{ (3) Question 1} & \multicolumn{2}{|c|}{ (4) Question 7} \\
\hline 1. Dollar return from self-interested choice & \multicolumn{2}{|c|}{$\$ 1.00$} & \multicolumn{2}{|c|}{$\$ 2.00$} & \multicolumn{2}{|c|}{$\$ 3.00$} \\
\hline 2. Relative price of giving & $\mathrm{B}: \$ 0.20$ & $\mathrm{C}: \$ 0.09$ & $\mathrm{~A}: \$ 0.67$ & $\mathrm{~B}: \$ 0.25$ & $\mathrm{~B}: \$ 1.50$ & $\mathrm{C}: \$ 0.75$ \\
\hline 3. Price of equity & \multicolumn{2}{|c|}{$\$ 0.14$} & \multicolumn{2}{|c|}{$\$ 0.29$} & \multicolumn{2}{|c|}{$\$ 0.38$} \\
\hline 4. Price of $\$ 1$ increase in total payoff & \multicolumn{2}{|c|}{$\$ 0.10$} & \multicolumn{2}{|c|}{$\$ 0.33$} & \multicolumn{2}{|c|}{$\$ 3.00$} \\
\hline 5. Percentage choosing self-interested choice & \multicolumn{2}{|c|}{$25.4 \%$} & \multicolumn{2}{|c|}{$28.7 \%$} & \multicolumn{2}{|c|}{$51.2 \%$} \\
\hline 5a. Men & \multicolumn{2}{|c|}{$22.5 \%$} & \multicolumn{2}{|c|}{$32.5 \%$} & \multicolumn{2}{|c|}{$55.0 \%$} \\
\hline 5b. Women & \multicolumn{2}{|c|}{$27.6 \%$} & \multicolumn{2}{|c|}{$26.8 \%$} & \multicolumn{2}{|c|}{$48.8 \%$} \\
\hline \multicolumn{7}{|c|}{$\begin{array}{l}\text { Changes in the Probability of Switching to a Self-Interested Allocation } \\
\text { as the Price of Being Unselfish Increases } \\
\text { (derived from probit equations; p-values in parentheses) }\end{array}$} \\
\hline $\begin{array}{c}(1) \\
\partial \operatorname{Prob}(\text { switch }) / \partial \mathbf{x}\end{array}$ & \multicolumn{3}{|c|}{$\begin{array}{l}(2) \\
\text { Switching to Self-interest } \\
\mathbf{Q 1 0} \rightarrow \mathbf{Q 7}\end{array}$} & \multicolumn{3}{|c|}{$\begin{array}{l}\text { (3) } \\
\text { Switching to Self-interest } \\
\mathbf{Q 1} \rightarrow \mathbf{Q 7}\end{array}$} \\
\hline 6. Gender & \multicolumn{3}{|c|}{$\begin{array}{c}0.103 \\
(0.275)\end{array}$} & \multicolumn{3}{|c|}{$\begin{array}{c}0.066 \\
(0.479)\end{array}$} \\
\hline 7. Self-interested & \multicolumn{3}{|c|}{$\begin{array}{l}0.456^{* * *} \\
(0.009)\end{array}$} & & Droppe & \\
\hline 8. Competitive Inequity Averter & & $\begin{array}{r}-0.399 * * \\
(0.002)\end{array}$ & & & $\begin{aligned}-0.338^{*} * \\
(0.002)\end{aligned}$ & \\
\hline $\begin{array}{l}\text { 9. Weakly Compassionate Inequity } \\
\text { Averter }\end{array}$ & & $\begin{array}{l}-0.199 \\
(0.144)\end{array}$ & & & $\begin{array}{r}-0.258^{*} \\
(0.046)\end{array}$ & \\
\hline $\begin{array}{l}\text { 10. Strongly Compassionate Inequity } \\
\text { Averter }\end{array}$ & & $\begin{array}{r}-0.377^{* *} \\
(0.012)\end{array}$ & & & $\begin{array}{l}-0.214 \\
(0.064)\end{array}$ & \\
\hline 11. Efficiency Maximizer & & $\begin{array}{c}0.041 \\
(0.735)\end{array}$ & & & $\begin{array}{l}-0.011 \\
(0.924)\end{array}$ & \\
\hline $\begin{array}{l}\text { 12. Weakly Compassionate Social } \\
\text { Surplus Maximizer }\end{array}$ & & $\begin{array}{l}-0.156 \\
(0.359)\end{array}$ & & & $\begin{array}{l}-0.226 \\
(0.148)\end{array}$ & \\
\hline $\begin{array}{l}\text { 13. Strongly Compassionate Social } \\
\text { Surplus Maximizer }\end{array}$ & & $\begin{array}{c}0.012 \\
(0.938)\end{array}$ & & & $\begin{array}{l}-0.019 \\
(0.894 \\
\end{array}$ & \\
\hline 14. Pseudo R-squared & & 0.177 & & & 0.085 & \\
\hline 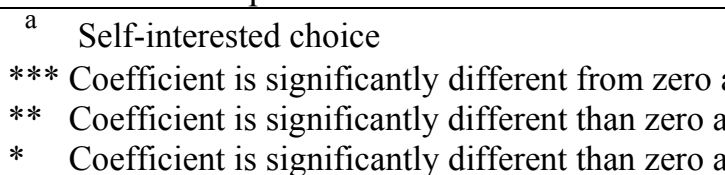 & $\begin{array}{l}t \text { the } 0.01 \\
\text { the } 0.051 \\
\text { the } 0.101\end{array}$ & & & & & \\
\hline
\end{tabular}


equity in questions 1 and 7 are $\$ 0.29$ and $\$ 0.38$ respectively. Choosing social surplus maximization rather than the self-interested choice in question 10 (answer $\mathrm{C}$ rather than $\mathrm{A}$ ) increases the total value of payoffs by $\$ 10$ by giving up $\$ 1$, so the price of raising the social surplus is $\$ 0.10$. The corresponding prices of choosing the social surplus maximization choices in questions 1 and 7 are $\$ 0.33$ and $\$ 3.00$. Therefore, the returns to being self-interested or the price of unselfishness, regardless of how they are calculated, are highest in question 7 and lowest in question 10.

Row 5 presents the percent of respondents picking the self-interested allocation for each question. As hypothesized, the percentage choosing the self-interested allocation is lowest in question $10(25.4 \%)$ and highest in question 7 (51.2\%). Interestingly men appear to be more sensitive to the changing prices as the percentage choosing the self-interested allocation increases from $22.5 \%$ to $55.0 \%$ (change of 32.5 percentage points) while the percentage of women choosing self interest only increases from $27.6 \%$ to $48.8 \%$ (change of 21.2 percentage points). ${ }^{19}$ However, this does not take into account the responses of different social preferences categories; if inequity averters respond to price differences differently than social surplus maximizers, the gender differences could be due to different proportions of men and women who are categorized as inequity averters and social surplus maximizers rather than a pure gender effect. We investigate this below.

To determine if there are any predictors of who switches to the self-interested allocation with increased costs of being unselfish, we run a probit analysis to predict the probability of switching. ${ }^{20}$ The lower half of Table 7 presents these results. Column two presents the results

\footnotetext{
${ }^{19}$ This is consistent with Andreoni and Vesterlund's (2001) finding that men respond more to the price of giving than do women.

${ }^{20}$ We use the probit analysis rather than logit since it allows easier interpretation of coefficients and we do not have to worry about multi-category dependent variables.
} 
when the switching occurs between question 10, with the lowest cost of selflessness, and question 7, with the highest cost of selflessness. Column three presents the results associated with the switch between question 1 , which has an intermediate cost of selflessness, and question 7. In both instances the sample of the analysis includes only those who do not choose the selfish allocation initially. ${ }^{21}$ The independent variables include dummy variables for the seven different categories and a dummy variable for gender.

The results are very strong. As expected, individuals who are categorized as selfinterested are likely to switch to the self-interested allocation if they have not already chosen selfishly. Therefore, being categorized as self-interested by the first four questions increases the probability of picking selfishly in question 7 , conditional on not choosing selfishly in question 10, by 46 percentage points ( row 7, column 2). All the individuals classified as selfish picked the selfish allocation in question 1 , so we can not estimate a selfish coefficient for the third column analysis. More striking however are the large negative coefficients on the inequity averter categories. Relative to the omitted category (unclassified) and the social surplus maximizing categories, inequity averters are significantly less likely to switch to the selfish allocation and the effects are as large as a reduction of 40 percentage points in the probability for competitive inequity averters. The analysis of the switch from a non-self-interested response in question 1 to a selfish response in question 7 gives similar results. The three types of inequity averters are significantly less likely to switch than those who cannot be classified and than at least two of the three social surplus maximizer groups: efficiency maximizers and strongly compassionate social surplus maximizers. Interestingly, gender does not have a significant effect

\footnotetext{
${ }^{21}$ We do not estimate the change equation for switches from question 10 to question 1 because there are not many switchers and a majority of the switchers are selfish since by definition a selfish person must choose the selfish allocation in question 1 .
} 
on switching, controlling for social preference category. This implies that gender differences in price responsiveness are due to differences in classification of preferences and not gender per se.

There are several possible explanations for the big difference in switching between social surplus maximizers and inequity averters. First, the increase in price of increasing the total payoff (line 4: $\$ 0.10$ to $\$ 3.00$ ) is much higher than the increase in the price of equity (line 3: $\$ 0.14$ to $\$ 0.38$ ) between the three equations suggesting that social surplus maximizers would be less willing to be unselfish. Second, question 7 offers a perfectly equal outcome, which may have influenced inequity averters to choose that allocation rather than move to self-interest. Third, it may be that inequity averters are more committed to their objective of seeking fairness than social surplus maximizers are to their goal of maximizing surplus so that they are less likely to respond to changes in the cost of being unselfish by making selfish choices.

\section{VI.B. Do people act more compassionately when payoff gaps for the worst-off are larger?}

If individuals care about the payoffs to others, they may respond differently to allocations that incorporate a very low absolute payoff to the worst-off person or to large payoff gaps. In particular, one might expect the self-interested, the competitive inequity averter, and efficiency maximizer to act more compassionately when payoffs to others are very low. To test this hypothesis we compare answers to questions 3 and 5, where there are no costs to oneself in choosing between allocations (the payout is the same for all three choices) and the costs of giving up social surplus to reduce inequality are the same, but the payoff gaps are larger and the payoff to the worst-off person is far lower in question 5 than in question $3 .^{22}$ In both questions

\footnotetext{
${ }^{22}$ In particular, choosing $\mathrm{B}$ rather than $\mathrm{A}$ in question 3 and $\mathrm{A}$ rather than $\mathrm{C}$ in question 5 reduces total surplus by $\$ 1$ and reduces total inequality by $\$ 3$ in both cases. Choosing $\mathrm{C}$ rather than $\mathrm{B}$ in question 3 and $\mathrm{B}$ rather than $\mathrm{A}$ in 5 reduces total payoff by $\$ 4$ in both questions leaving the total inequality unchanged. However, the competitive inequity averse choice entails $\$ 2$ total inequality in payoffs in question 3 and $\$ 6$ in question 5, while the worst-off person receives $\$ 5$ in question 3 and only $\$ 1$ in question 5. Similarly, the efficiency maximizing answer entails total
} 
the compassionate allocation ( $\mathrm{B}$ and A respectively) is potentially the choice for both the compassionate inequity averter and the compassionate social surplus maximizer

The results presented in Table 8 reveal a substantial increase in the numbers choosing the compassionate allocation at the expense of competitive inequity aversion or efficiency.

Comparing answers to question 5 to those of question 3 , the percentage choosing the compassionate allocation increases from $27.5 \%$ in question 3 to $52.2 \%$ in question 5 (row 1 ). While both men and women increase compassionate allocation choices, the percentage increase is slightly higher for women $(27 \%)$ than for men $(20 \%)$. In this scenario women seem more sensitive to payoff gaps than men.

Again, we run a probit equation to determine if there are any predictors of who switches to the compassionate allocation. The lower half of Table 8 presents these results in Column 2 . Anyone who picked the compassionate allocation in question 3 is not included in the analysis and the independent variables include dummy variables for the seven different categories and a dummy variable for gender.

Again the preference categories are powerful predictors of who switches to the compassionate allocation. Selfish individuals are 27 percentage points less likely to switch than the unclassified and efficiency maximizers are 46 percentage points less likely to switch. Those who are most likely to switch are the non-classified and the inequity averters. The coefficient on gender is small and insignificant. Therefore, more women switch to compassionate allocations when others are more disadvantaged, not because of their gender per se but because inequity averters are more sensitive to payoff gaps than social surplus maximizers and women are more likely to be inequity averters.

inequality of $\$ 5$ in question 3 and $\$ 9$ in question 5 , while the worst-off person receives $\$ 5$ in the former and $\$ 2$ in the latter. 
Table 8

Number and Percentage Shifting Choice to Compassionate Allocation When Payoff Gaps are Large for the Worst-off Person

\begin{tabular}{|c|c|c|c|c|}
\hline \multicolumn{5}{|c|}{ Allocation Choices } \\
\hline \multicolumn{2}{|c|}{ Question 3} & \multicolumn{3}{|c|}{ Question 5} \\
\hline $\mathbf{X} \quad \mathbf{Y} \quad \mathbf{Z}$ & Total Payoff & & $\mathbf{Y Z}$ & Total Payoff \\
\hline $\begin{array}{llll}\mathbf{A} & 10 & 6 & 5 \\
\end{array}$ & 21 & $\mathbf{A}$ & $73^{\mathrm{a}}$ & 19 \\
\hline B $\quad 866^{\mathrm{a}}$ & 20 & B & $7 \quad 1$ & 15 \\
\hline $5 \quad 6 \quad 5$ & 16 & $\mathbf{C}$ & 72 & 20 \\
\hline \multicolumn{5}{|c|}{ Percentage Choosing the Compassionate Allocation (either IA or SSM) } \\
\hline \multicolumn{2}{|c|}{$\begin{array}{c}\text { (1) } \\
\text { Question 3 } \\
\text { Small Gap with Worst-off } \\
\end{array}$} & \multicolumn{3}{|c|}{$\begin{array}{c}\text { (2) } \\
\text { Question 5 } \\
\text { Large Gap with Worst-off }\end{array}$} \\
\hline \multicolumn{2}{|c|}{$27.5 \%$} & \multicolumn{3}{|c|}{$52.2 \%$} \\
\hline 1a. Men & $30.0 \%$ & \multicolumn{3}{|c|}{$50.0 \%$} \\
\hline 1b. Women & $26.0 \%$ & \multicolumn{3}{|c|}{$53.5 \%$} \\
\hline \multicolumn{5}{|c|}{$\begin{array}{l}\text { Changes in the Probability of Switching to a Compassionate Allocation } \\
\text { as the Gaps in Payoffs Increase } \\
\text { (derived from probit equations; p-values in parentheses.) }\end{array}$} \\
\hline \multicolumn{2}{|c|}{$\begin{array}{c}(1) \\
\partial \operatorname{Prob}(\text { switch }) / \partial \mathbf{x}\end{array}$} & \multicolumn{3}{|c|}{$\begin{array}{c}(2) \\
\text { Switching to Compassionate: } \mathrm{Q3} \rightarrow \mathrm{Q5}\end{array}$} \\
\hline \multicolumn{2}{|l|}{ 1. Gender } & \multicolumn{3}{|c|}{$\begin{array}{c}-0.041 \\
(0.667)\end{array}$} \\
\hline \multicolumn{2}{|l|}{ 2. Selfish } & \multicolumn{3}{|c|}{$\begin{array}{l}-0.272 * * \\
(0.018)\end{array}$} \\
\hline \multicolumn{2}{|c|}{ 3. Competitive Inequity Averter } & \multicolumn{3}{|c|}{$\begin{array}{l}-0.022 \\
(0.896)\end{array}$} \\
\hline \multicolumn{2}{|c|}{$\begin{array}{l}\text { 4. Weakly Compassionate Inequity } \\
\text { Averter }\end{array}$} & \multicolumn{3}{|c|}{$\begin{array}{l}-0.094 \\
(0.582)\end{array}$} \\
\hline \multicolumn{2}{|c|}{$\begin{array}{l}\text { 5. Strongly Compassionate Inequity } \\
\text { Averter }\end{array}$} & \multicolumn{3}{|c|}{ Dropped $^{b}$} \\
\hline \multicolumn{2}{|c|}{ 6. Efficiency Maximizer } & \multicolumn{3}{|c|}{$\begin{array}{l}-0.460 * * * \\
(0.000)\end{array}$} \\
\hline \multicolumn{2}{|c|}{$\begin{array}{l}\text { 7. Weakly Compassionate Social } \\
\text { Surplus Maximizer }\end{array}$} & \multicolumn{3}{|c|}{-0.143} \\
\hline \multicolumn{2}{|c|}{$\begin{array}{l}\text { 8. Strongly Compassionate Social } \\
\text { Surplus Maximizer }\end{array}$} & \multicolumn{3}{|c|}{ Dropped ${ }^{b}$} \\
\hline \multicolumn{2}{|c|}{ 9. Pseudo R-squared } & & & \\
\hline $\begin{array}{l}\text { a Compassionat } \\
\text { b The individual } \\
\text { definition they } \\
* * * \text { Coefficient is } \\
* * \text { Coefficient is }\end{array}$ & $\begin{array}{l}\text { gly compassiona } \\
\text { mpassionate all } \\
\text { different than ze } \\
\text { different from ze }\end{array}$ & $\begin{array}{l}\text { ories a } \\
\text { n ques } \\
0.011 \\
0.05\end{array}$ & cluded & alysis since by \\
\hline
\end{tabular}


We also examine how individuals respond to increased returns to efficiency maximization. For example, comparing question 4 to question 9 , the extra total payoff gained by moving from the totally equal allocation to the efficiency maximization allocation is greater in question $9(\$ 8)$ than in question $4(\$ 2)$. Similarly the extra total payoff gained by turning down the compassionate allocation for the efficiency maximization allocation is $\$ 3$ in question 9 and $\$ 1$ in question 4 . However there are very few people (16) who switch to the efficiency maximization choice in question 9. Of the eleven classifiable individuals who switch, seven are social surplus maximizers, three are selfish and only one is a compassionate inequity averter. The character and extent of this switching behavior underlines the remarkable consistency that other-regarding individuals display over the ten question experiment. Those categorized in the first four questions as social surplus maximizers, continue to act as social surplus maximizers in subsequent allocation exercises and are responsive to the price of being unselfish or efficiency gains but relatively insensitive to payoff gaps. Similarly, the inequity averter is consistent in his or her preferences while being sensitive to payoff gaps but unmoved by big changes in the price of being unselfish or efficiency gains.

\section{Conclusion}

The current study expands on previous work on other-regarding behavior in three important ways. First, we explicitly model social preferences to include a definition of compassionate behavior. Consideration of maximin preferences by earlier authors (Charness and Rabin, 2002 for example) comes closest to an acknowledgment of compassion, however, there has been no attempt to separate the maximin motivation from other seemingly consistent social preferences. Second, we track individual responses to ten allocation questions in order to categorize individuals according to preferences and to determine how individual characteristics 
affect preference categorization. While there are isolated instances of tracking within person decisions, most studies analyze questions independently and make inferences about preferences within the group based on aggregated answers. Finally, we investigate how individuals respond to changing costs of self-interest and changing payoff gaps.

The dictator experiments reveal that the vast majority of people (87\%) make one or more allocation decisions that are other-regarding in that they accept a lower payoff to self in order to raise payoffs to others. We are able to categorize $65 \%$ of the participants as always choosing allocations consistent with one of the preference categories: self-interest, inequity aversion, or social surplus maximization. Only $14 \%$ of the participants are always self-interested and the rest who can be categorized are roughly split between inequity averters and social surplus maximizers.

There are significant gender differences in social preferences; men are less likely to be inequity averters than social surplus maximizers (10\% compared to $38 \%)$ while women are more likely to be inequity averters than social surplus maximizers (38\% compared to $17 \%)$, and these results hold up in multivariate analyses. Dickinson and Tiefenthaler (2002) and Fehr, Naf, and Schmidt (2005) also find that women make more equitable choices than men. Analogous to this finding, Andreoni and Vesterlund (2001), who conduct giving experiments with varying prices of giving, find women to have preferences resembling Leontief utility functions while men are more often self-interested or treat giving to self and others as perfect substitutes by choosing allocations that maximize total payoffs. Their conclusion that men are more price responsive than women results from the fact that at a price greater than one, when giving to others reduces social surplus, men give less than women, while at a price less than one, when giving increases 
social surplus, they give more than women. Our results suggest that the greater price sensitivity may be more the result of men being social surplus maximizers rather than their being male.

Like other studies (Carter and Irons (1991), Frank, Gilovich and Regan (1993), Marwell and Ames (1981), Dickinson and Tiefenthaler (2002), and Fehr, Naf, and Schmidt (2005)) we find that that business majors and economics majors differ from other majors; here business and economics majors are less likely to be inequity averters. But within the social surplus classifications, business majors tend to be efficiency maximizers and economics majors tend to be weakly compassionate social surplus maximizers. However, while multivariate analysis supports the preference categorization of business majors, it reveals that the pattern displayed by economics majors is due to their gender, which is predominantly male, rather than due to their major.

We find compassion to be an important source of other-regarding behavior, with $59 \%$ of those who can be classified falling in either weakly or strongly compassionate categories. Inequity averters are more often found to be weakly or strongly compassionate (88\%) than social surplus maximizers (59\%). Of those who can be classified, $50 \%$ of men and $64 \%$ of women are in one of the compassionate categories, and probits show that being female increases the likelihood of being weakly rather than not compassionate and being a business major reduces the probability of being compassionate.

Individuals respond to changing incentives in expected ways. Comparing allocation decisions when the price of being unselfish rises, we find that the percentage of respondents who choose the self-interested allocation increases significantly. Probits reveal that those who are classified as inequity averse are significantly less likely to switch to a self-interested allocation than are social surplus maximizers. We also find that significantly more people choose the 
compassionate allocation when the alternative entails large payoff gaps or a very low payoff to the worst-off person. Probits show that those most likely to switch to a compassionate allocation are inequity averters and unclassified, while the self-interested and social surplus maximizers are the least likely to switch.

The results of this study verify that individuals have heterogeneous preferences, that gender and major or career are linked to different types of preferences, that compassion is an important motivator for a large majority of people, and that people respond in expected ways to the price of giving and payoff differences. Our findings may help explain the puzzle of why some studies find gender differences in altruism while others do not: experiments that do not provide the opportunity to increase the total social surplus (e.g. fixed pot dictator games) may underestimate men's altruism if they are predominantly social surplus maximizers. It also explains why men may give more than women when the price of giving is less than one; in this circumstance, giving raises the total social surplus while giving decreases the surplus when the price exceeds one.

Disagreements over whether inequity aversion or social surplus maximization dominates individuals' preferences can be explained by the mix of participants in the studies; experiments conducted with more economics and business majors or males will find proportionately more social surplus or efficiency maximizers while those with more other majors and women will find a greater number of inequity averters. Thus economic studies must be careful to take into consideration heterogeneous preferences when drawing conclusions from experimental exercises.

The examination of switching behavior provides a check on the consistency of behavior defined by initial categorization. We find individuals to be very consistent in their choices. 
Inequity averters respond more to large payoff disparities with those who are worse-off but are less likely to react to the price of being unselfish or large efficiency gains. On the other hand, social surplus maximizers respond more to the price of being unselfish and potentially large efficiency gains but not to larger payoff differences.

While there is some evidence suggesting women are somewhat more compassionate than men, the more striking finding is that men and women are compassionate in different ways; women tend to be compassionate from an inequity averse orientation while men are compassionate acting as social surplus maximizers. 


\section{References}

Andreoni, James and Lise Vesterlund (2001). 'Which is the Fair Sex? Gender Differences in Altruism.' The Quarterly Journal of Economics, pp. 293-312.

Baum, Sandy, Linda Kamas, and Anne Preston (2006). "Altruistic Responses to the September $11^{\text {th }}$ Terrorist Attacks: Some Evidence from Dictator Games," Eastern Economic Journal, vol. 31, n.4, pp. 551-562

Ben-Ner, Avner, Fanmin Kong, and Louis Putterman (2002). 'Share and Share Alike? Intelligence, Socialization, Personality, and Gender-Pairing as Determinants of Giving.' Unpublished manuscript, University of Minnesota, Peking University, and Brown University.

Bolton, Gary and Elena Katok (1995). 'An Experimental Test for Gender Differences in Beneficent Behavior.’ Economics Letters, vol. 48, pp. 287-92.

Bolton, Gary E. and Axel Ockenfels (2000). 'ERC: A Theory of Equity, Reciprocity, and Competition.' American Economic Review, vol. 90, n. 1, March, 166-193.

Carter, John and Michael Irons (1991). 'Are Economists Different, and If So, Why?' Journal of Economic Perspectives, vol. 5, n. 2, pp. 171-77

Cason, Timothy N. and Vai-Lam Mui (1997). 'A Laboratory Study of Group Polarisation in the Team Dictator Game.’ The Economic Journal, vol. 107, pp. 1465-83.

Charness, Gary and Matthew Rabin ( 2002). 'Understanding Social Preferences with Simple Tests.' Quarterly Journal of Economics, August, 817-869.

Cox, James C. (2002). 'Trust, Reciprocity, and Other-Regarding Preferences: Groups vs. Individuals and Males vs. Females,' in Rami Zwick and Amnon Rapoport, Advances in Experimental Business Research. Kluwer Academic Publishers.

and Cary A. Deck (2002). 'When Are Women More Generous than Men?' unpublished manuscript, University of Arizona and University of Arkansas.

and Vjollca Sadiraj (2005). 'Direct Tests of Models of Social Preferences and a New Model, mimeo, University of Arizona and Indiana University, February 2005.

Croson, Rachel and Uri Gneezy (2004). 'Gender Differences in Preferences.' mimeo, University of Pennsylvania.

Dickinson, David L. and Jill Tiefenthaler (2002). 'What Is Fair? Experimental Evidence.' Southern Economic Journal, vol. 69, pp. 414-28.

Dufwenberg, Martin and Astri Muren (2002). 'Discrimination by Gender and Social Distance.' Unpublished manuscript, Stockholm University. 
Eckel, Catherine and Philip Grossman (1996). 'Altruism in Anonymous Dictator Games.' Games and Economic Behavior, vol. 16, pp. 181-191.

(1998). 'Are Women Less Self-interested than Men? Evidence from Dictator Experiments.' The Economic Journal, vol. 107, pp. 726-35.

(2000). 'Differences in the Economic Decisions of Men and Women:

Experimental Evidence,' in Plott and Smith, eds., Handbook of Experimental Results. Amsterdam: Elsevier.

Engelmann, Dirk and Martin Strobel (2004). 'Inequity Aversion, Efficiency, and Maximin Preferences in Simple Distribution Experiments.' American Economic Review, v. 94, n. 4, September.

(2005A). "Fairness on the Internet - The Role of Distributional Concerns in Dictator Games with High Social Distance. Mimeo.

(2005B). 'Preferences over Income Distributions, Experimental Evidence.' Mimeo, Andrew Young School of Policy Studies, Georgia State University.

Fehr, Ernst, Michael Naf, and Klaus M. Schmidt (2005). 'The Role of Equality and Efficiency in Social Preferences.' Discussion Paper 2005-19, Department of Economics, University of Munich, February.

Fehr, Ernst and Klaus M. Schmidt ( 1999). 'A Theory of Fairness, Competition, and Cooperation.' The Quarterly Journal of Economics, August, 817-868.

Fisman, Raymond J., Shachar Kariv, and Daniel Markovits (2005A). 'Individual Preferences for Giving.' Working Paper No. XL05-003, Institute of Business and Economic Research, Experimental Social Science Laboratory, University of California, Berkeley, February. (2005B).'Distinguishing Social Preferences from Preferences for Altruism.' Public Law \& Legal Theory Research Paper Series, no 99, Center for Law, Economics and Public Policy, no. 314, Yale Law School, August.

Frank, Robert H., Thomas Gilovich, and Dennis T. Regan (1993). 'Does Studying Economics Inhibit Cooperation?' Journal of Economic Perspectives, vol. 7, n. 2 159-171.

Kamas, Linda, Anne Preston, and Sandy Baum (2005). 'Altruism in Anonymous and Social Settings: What's Gender Got to do with it?' Working Paper, Santa Clara University.

Loewenstein, George F., Leigh Thompson, and Max H. Bazerman (1989). "Social Utility and Decision Making in Interpersonal Contexts." Journal of Personality and Social Psychology, v. 57, no. 3, 426-441. 
Marwell, Gerald and Ruth Ames (1981). 'Economists Free Ride, Does Anyone Else?:

Experiments on the Provision of Public Goods, IV.' Journal of Public Economics, vol.15, n. 3, 295-310. 